\title{
Citizens' Views About the Proposed Hartsville Nuclear Power Plant: A Survey of Residents' Perceptions in August 1975
}
E. D. Sundstrom
L. J. Costomiris
R. C. DeVault
D. A. Dowell
J. W. Lounsbury
T. J. Mattingly, J r.
E. M. Passino
E. Peelle

\section{OAK RIDGE NATIONAL LABORATORY}




\section{DISCLAIMER}

This report was prepared as an account of work sponsored by an agency of the United States Government. Neither the United States Government nor any agency Thereof, nor any of their employees, makes any warranty, express or implied, or assumes any legal liability or responsibility for the accuracy, completeness, or usefulness of any information, apparatus, product, or process disclosed, or represents that its use would not infringe privately owned rights. Reference herein to any specific commercial product, process, or service by trade name, trademark, manufacturer, or otherwise does not necessarily constitute or imply its endorsement, recommendation, or favoring by the United States Government or any agency thereof. The views and opinions of authors expressed herein do not necessarily state or reflect those of the United States Government or any agency thereof. 


\section{DISCLAIMER}

Portions of this document may be illegible in electronic image products. Images are produced from the best available original document. 


\section{Printed in the United States of America. Available from National Technical Information Service \\ U.S. Department of Commerce \\ 5285 Port Royal Road, Springfield, Virginia 22161 \\ Price: Printed Copy $\$ 5.00$; Microfiche $\$ 3.00$}

This report was prepared as an account of work sponsored by the United States Government. Neither the United States nor the Energy Research and Development Administration/United States Nuclear Regulatory Commission, nor any of their employees, nor any of their contractors, subcontractors, or their employees, makes any warranty, express or implied, or assumes any legal liability or responsibility for the accuracy, completeness or usefulness of any information, apparatus, product or process disclosed, or represents that its use would not infringe privately owned rights. 
ORNL/TM-5801

Contract No. W-7405-eng-26

CITIZENS' VIEWS ABOUT THE PROPOSED HARTSVILLE NUCLEAR POWER PLANT:

A SURVEY OF RESIDENTS' PERCEPTIONS IN AUGUST 1975

E. D. Sundstrom

L. J. Costomiris

R. C. DeVault

D. A. Dowell

J. W. Lounsbury

T. J. Mattingly, Jr.

E. M. Passino

E. Peelle

Energy Division

Date Published - May 1977

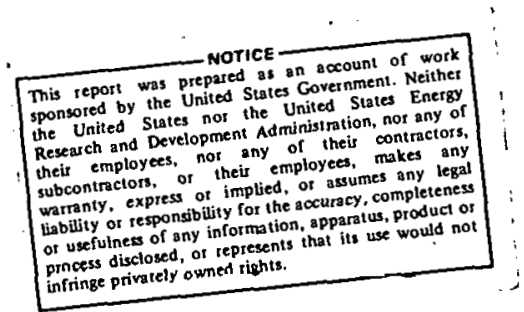

Research sponsored by the Energy Research and Development Administration, Division of Technology Overview, under contract with the Union Carbide Corporation.

OAK RIDGE NATIONAL LABORATORY

Oak Ridge, Tennessee 37830

Operated by Union Carbide Corporation for the

Energy Research and Development Administration 
THIS PAGE

\section{WAS INTENTIONALLY \\ LEFT BLANK}


LIST OF FIGURES ................................ vii

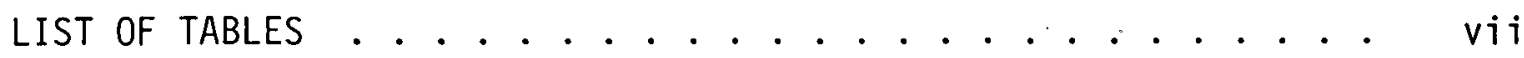

ACKNOWLEDGMENTS .......................... $i x$

ABSTRACT .................................

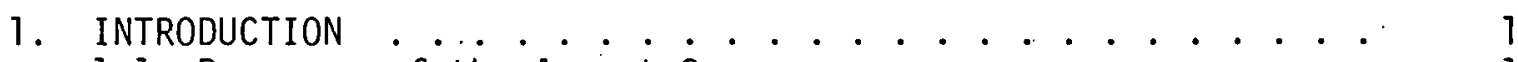

1.1 Purposes of the August Survey . . . . . . . . . . 1

1.1.1 Factors related to attitudes toward the nuclear facility ............ . . 2

1.1.2 Indicators of the perceived quality of life... 4

1.1.3 The link between attitudes toward the nuclear plant and perceived quality of life ..... 4

1.2 The Place of the August Survey in the Social Impact Analysis ................. . 4

1.3 Plan of the Report.............. 7

2. THE COMMUNITY AND THE NUCLEAR POWER PLANT . . . . . . . . 7

2.1 The Community: Hartsville and Trousdale County . . . . 7

2.2 TVA and the Nuclear Power Plant ......... 8

2.3 TVA's Plans for Mitigation of Adverse Socioeconomic
Impacts . . . . . 10

3. METHODS USED IN COLLECTING AND ANALYZING THE DATA ..... 11

3.1 Design . . . . . . . . . . . . . . . 11

3.2 Procedures . . . . . . . . . . . . 11

3.2.1 Sampling procedure ............ 11

3.2.2 Interviewing procedure . . . . . . . . . . . 12

3.2.3 The questionnaire ........... . . 12

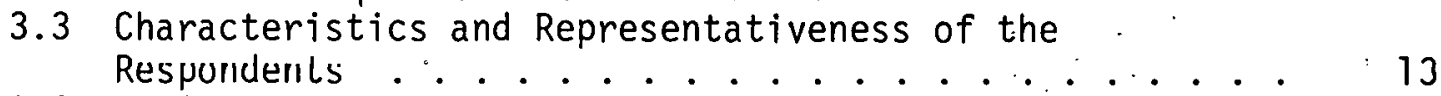

3.4 Analysis of the Data . . . . . . . . . . . 14

4. SUPPORT VS. OPPOSITION TO THE NUCLEAR POWER PLANT AND

ATTITUDES TOWARD RELATED ISSUES . . . . . . . . . 15

4.1 Favorability Toward the Nuclear Plant . . . . 15

4.1.1 Distribution of support and opposition to the facility......... 15

4.1.2 Consistency of responses from January to August. . . . . . . . . . 16

4.1.3 Consistency among responses to different questions about attitudes toward the nuclear plant .................. 19

4.2 Attitudes Toward TVA's Performance......... 21

4.3 Attitudes Toward a Coal-burning Plant Instead of a Nuclear Plant 
5. ATTITUDES TOWARD THE NUCLEAR PLANT AS A FUNCTION OF

ITS ANTICIPATED EFFECTS . . . . . . . . . . . 26

5.1 Perceived Likelihood of Potential Effects of the

Nuclear Plant......... . . 26

5.1.1 Estimates of the likelihood of effects

in August . . . . . . . . . 26

5.1.2 Grouping of the potential effects ...... 26

5.1.3 Consistency of perceived likelihood from January to August ......... 28

5.2 Perceived Desirability of Potential Effects of the Nuclear Plant ............ . 28

5.2.1 August ratings of desirability ........ 28

5.2.2 Consistency of ratings of desirability from January to August ........ 30

5.3 Relationship of Likelihood of Effects and Desirability of Effects .......... . 30

5.4 Support vs. Opposition to the Nuclear Plant and Anticipated Effects ............ 30

5.4.1 Differences between supporters and opponents
in estimates of likelihood . . . . . 30

5.4.2 Variation in favorability toward the plant as a function of anticipated effects ..... 33

6. DEMOGRAPHIC CHARACTERISTICS AND ATTITUDES TOWARD THE

NUCLEAR PLANT ...................... 36

6.1 Demographic Differences Between Supporters and Opponents .......... 36

6.2 Demographic Differences in Estimates of Likelihood of Effects of the Plant . . . . . . . . 37

7. ATTITUDES TOWARD THE NUCLEAR PLANT AND INFORMATION ABOUT IT . 39

7.1 Respondents' Knowledge and Information about the Nuclear Plant ............ . . . . 39

7.1.1 Factual knowledge ............. 39

7.1 .2 Sources of information ........... 40

7.2 Support vs. Opposition to the Nuclear Plant as a

Function of Information About it ........ 40

8. INDICATORS OF THE PERCEIVED QUALITY OF LIFE IN HARISVILLE . . 43

8.1 Changes in Indicators of the Perceived Quality of Life . 43

8.1.1 Satisfaction with services ....... 43

8.1.2 Ratings of characteristics of neighborhoods . . . 43

8.1.3 General evaluations of the quality of life . . 47

8.2 Attitudes Toward the Nuclear Plant and the Perceived

Quality of Life ................ 49

8.2.1 Support vs. opposition and ratings of services. 49

8.2.2 Support $\frac{v s}{v s}$. opposition and percefved characteristics of neighborhoods ...... 49

8.2.3 Support vs. opposition and general evaluations of the quality of life ......... 
9. INTERPRETATION AND DISCUSSION OF THE RESULTS OF THE

AUGUST SURVEY . . . . . . . . . . . . . . . . . . . . 51

9.1 Subjective Reactions to the Nuclear Plant ....... 51

9.1.1 The proportions of support and opposition to the nuclear plant ............. 51

9.1.2 Consistency of attitudes toward the nuclear plant................. . 52

9.1.3 Attitudes toward TVA's performance . . . . . . 52

9.1.4 Attitudes toward a coal-fired plant instead of a nuclear plant ............. . 52

9.1.5 Support vs. opposition and expectations about the effects of the nuclear plant . . . . 53

9.1.6 Demographic differences in support vs. opposition and anticipated effects of the facility ................ . 54

9.1.7 Factual knowledge and sources of information about the facility ........... . 56

9.1.8 The perceived quality of life .......... 56

9.1.9 The relationship of perceived quality of life and attitudes toward the facility .... . 57

9.1.10 Potential consequences of subjective responses . 57

9.2 Unanswered Questions About Subjective Responses to the Nuclear Plant. ............... . 58

9.3 Practical Implications . . . . . . . . . . . . 59

9.4 Conclusions . . . . . . . . . . . . . . . . 60

10. NOTES AND REFERENCES ........................... 61 
THIS PAGE

\section{WAS INTENTIONALLY \\ LEFT BLANK}




\section{LIST OF FIGURES}

Figure

Page

2.1 Map of the Hartsville area showing the site of the nuclear plant.....................

\section{LIST OF. TABLES}

Table

$\underline{\text { Page }}$

1.1 Major Variables and Techniques in the Analysis of

Social Impacts ....................

4.1 Distribution of Responses in January and August to the Question, "If it were up to you, would you permit construction of the TVA power plant near Hartsville?" . .

4.2 Consistency from January to August in Responses to the Question, "If it were up to you, would you permit construction of the TVA power plant near Hartsville?" . .

4.3 Distribution of Respondents whose Answer to the "Permit Construction" Question Changed from January to August .....................

4.4 Responses to the Question, "If you could decide where the plant were to be located, how close to your home in miles, would you permit it to be built?" and their relationship with responses to the "Permit Construction" Question..................

4.5 Consistency Among Responses to Questions Used to Measure Attitudes Toward the Nuclear Plant . . . . .

4.6 Responses to the Question, "In general, how good a job do you think TVA is doing?"............

4.7 Relationship Between Support vs. Opposition to the Nuclear Plant and Support vs. Opposition to a CoalBurning Plant Instead of a Nuclear Plant . . . . . .

4.8 Attitudes Toward the Proposed Nuclear Plant or a Coal-Burning Facjlity Instead: How Important is the Use of Nuclear Fuel? .. . . . . . . . . . . . .

5.1 Perceived Likelihood of 27 Potential Effects of the Nuclear Plant ...................

5.2 Perceived Desirability of 27 Potential Effects of the Nuclear Plant................. 


\section{LIST OF TABLES (Cont'd.)}

Table

Page

5.3 Summary of Perceived Likelihood and Desirability

of Potential Effects of the Nuclear Plant . . . . . . .

5.4 Support vs. Opposition to the Nuclear Plant and

Perceived Likelihood of Its Effects . . . . . . . . . .

5.5 Estimates of the Likelihood of Groups of Potential

Effects of the Nuclear Plant as Predictors of the

Composite Index of Favorability toward It . . . . . .

6.1 Demographic Characteristics of Supporters and

Opponents: Marital Status, Race, Sex, Employment

Status, Occupation, and Type of Residence . . . . . .

6.2 Demographic Characteristics of Supporters and

Opponents: Age, Education, and Years of Residence . .

6.3 Estimates of the Likelihood of Effects of the

Proposed Nuclear Plant as a Function of Demographic

Characteristics.................. 38

7.1 Factual Knowledge About the Nuclear Plant . . . . . . . 41

7.2 Supporters' and Opponents' Sources of Information about the Proposed Plant. . . . . . . . . . . 42

8.1 Satisfaction with Local Services . . . . . . . . . . 44

8.2 Ratings of Characteristics of Neighborhoods .. . . . . 46

8.3 General Evaluations of the Quality of Life in Hartsville....................

8.4 Support vs. Opposition to the Proposed Plant as a

Function of Perceived Quality of Life.......... 


\section{ACKNOWLEDGMENTS}

This report describes one of a series of studies of the social and psychological effects of the nuclear power generating facility that the Tennessee Valley Authority is now constructing five miles outside of Hartsville, Tennessee. ${ }^{1}$ The work described here was performed at 0ak Ridge Nationa 1 Laboratory under Contract No.W-7405-eng-26 for the Energy Research and Development Administration, Division of Biomedical and Environmental Research.

We appreciate the diligent work of the Trousdale Countians (listed alphabetically) who acted as interviewers for one of the surveys.

Martha Bode

Barbara June Cothron

Charlotte Dies

Mary Durham

Sandy Ford

Carolyn Gregory

Gloria Gregory

June Gregory

Lyzette Gregory

Vickie Holder

Donna Hudson
George Langford

Patricia Langford

Gladys Merryman

Judy Moore

Mamie Owens

Jeannie Reed

Janne Robertson

Rebecca Seay

Joy Turner

Annie Ferris Welch

Betty Witcher

Vanessa Williams

We would like to acknowledge the assistance of many residents of the Hartsville area, without whose support this project could not have been completed (1isted alphabetically):

Mrs. Ruth P. Carman, Hartsville-Trousdale County Coordinator of Federal Grants

Mr. Chester J. Davis, Radio Station WJKM, Hartsville, Tennessee

The Honorable James Donaho, Mayor of Hartsville

The Honorable Ray F. Foley, County Judge, Trousdale County

Mr. Phillip Ivey, Managing Editor, The Hartsvizle Vidette

Mrs. Patricia Langford, Secretary to the School Superintendent

Mr. Charles Robinson, Sheriff of Trousdale County

Mr. Jim Ross, Chief of Police, Hartsville

Mr. Jim B. Satterfield, Superintendent of the Trousdale County School System

Mr. Jim H. Spurling, Tennessee Game and Fish Commission

Mr. Barry 0. Taylor, Head of the Joint City-County Planning Commission of Hartsville and Trousdale County

Mr. and Mrs. James (Red) Williams, William's Motel and Grocery, Hartsville 
We are grateful for the support and cooperation of many members of the staff at Oak Ridge National Laboratory for their helpful comnents on earlier drafts of the report (listed alphabetically): Sam Beall, Ben Bronfman, Richard Davis, William Fulkerson, Bruce Purdy, Neil Ritchey, and Mark Shields. A note of thanks goes to Dovie Patterson who typed the report. We also appreciate thoughtful comments on an earlier draft by two members of the staff at the Tennessee Valley Authority, George Deveny and M. I. Foster. Finally, we wish to thank the participants in this research project for their cooperation and patience during the two surveys.

The main contributors to the project participated as follows in the phases of the project (1isted alphabetically):

(1) design of the questionnaire - David Dowe11, John Lounsbury, Thomas Mattingly, Emily Passino, and Eric Sundstrom;

(2) supervision of collection of the data in Hartsville Joyce Costomiris and Thomas Mattingly;

(3) coding of the data - Joyce Costomiris, David Dowell, Thomas Mattingly, and Emily Passino;

(4) design of analyses - John Lounsbury and Eric Sundstrom;

(5) computer work - Robert DeVault, David Dowe11, John I nunshury, Emily Passino, and Eric Sundstrom;

(6) prcliminary drafts of resulls - Dav1d Dowell, John Lounsbury, Emily Passino, and Eric Sundstrom;

(7) organization and writing of the report - Eric Sundstrom; and

(8) administration of the project - Elizabeth Peelle. 
This report describes the results of a survey conducted in August 1975 among a group of residents of Hartsville and Trousdale County, Tennessee, regarding their views about the nuclear power plant the Tennessee Valley Authority is constructing five miles outside of Hartsville. As part of a longitudinal study of the social impacts of the nuclear facility, the survey was conducted during the planning and pre-licensing phase of the project to address two questions: (1) What factors are related to favorable or unfavorable attitudes toward the nuclear plant? (2) How do residents of Hartsville perceive their quality of life, and how have their perceptions changed since an earlier survey in January 1975?

A panel of 288 residents interviewed in January 1975 was reinterviewed in August 1975. Trained local residents conducted one-hour interviews. Respondents received \$5.00 for participating. Questions concerned perceptions of the quality of life in Hartsville, knowledge and sources of information about the proposed nuclear plant, expectations regarding its effects on the community, and attitudes toward the plant and related issues.

A majority of the pane1, $69 \%$, said that if they could decide, they would permit the facility to be built. We called them "supporters." The remaining $31 \%$ opposed construction (called "opponents"). Results indicated that attitudes toward the proposed plant were consistent from January to August, and consistent when measured through different questions. Ratings of TVA's performance of its job were generally favorable; $74 \%$ of respondents gave "average" or higher ratings. Supporters of the nuclear plant gave TVA somewhat higher ratings than did opponents.

To examine importance of the use of nuclear fuel for attitudes toward the facility, we asked respondents if they would favor a similar facility that burned coal instead of using nuclear fuel. Most supporters of the nuclear plant would favor a coal-burning facility, while most opponents of the nuclear plant would oppose a coal-burning plant: Results showed that the differences between nuclear and coal-fired plants may have been critical for support or opposition to the nuclear plant for $25 \%$ of the respondents. 
Respondents rated the likelihood of several changes the nuclear plant could bring to Hartsville. Effects rated "likely" included events that might accompany economic expansion, such as increases in business, tourism, jobs, and industrial development. Also rated "likely" were social disruptions associated with growth, such as traffic congestion, crowded schools, increased noise, and increased crime. Respondents thought less likely the prospect of hazards to safety or environment such as radiation or pollution. Respondents saw economic expansion as "desirable" and social disruption and hazards as "very undesirable." Compared with opponents, supporters estimated economic expansion more likely, social disruption less likely, and hazards considerably less likely. However, supporters still rated social disruption as "likely," suggesting that they were willing to trade social disruption for economic expansion. Opponents apparently did not consider the benefits of economic expansion worth the costs and/or risks.

The average respondent correctly answered three or four of seven factual questions about the proposed facility (the mean was 3.6). The average respondent relied most on television and newspapers for information. Supporters were much more likely than opponents to rely on TVA for information about. the farility.

Support for the nuclear plant was relatively prevalent among managers and proprietors $(84 \%)$, salespersons, clerical workers, and blue collar workers $(75 \%)$, perhaps because of the likely increase in local business during the construction of the plant. Support was also prevalent among males $(76 \%)$, blacks (83\%), and persons who were employed (73\%). Only among farmers and farm workers were opponents a majority (56\% were opponent.s and $44 \%$ were supporters). People who lived on farms comprised about onefourth of a 11 respondents and included $53 \%$ supporters and $47 \%$ opponents. Opposition was also relatively prevalent among women (62\% were supporters; $38 \%$ were opponents) and unemployed persons (59\% were supporters; $41 \%$ were opponents).

Respondents indicated that they were very satisfied with life in Hartsville, as in January. Community services received high ratings, except that respondents were dissatisfied with the unavalability of housing. Neighborhoods also received high ratings, for example, as "private, quiet, and uncrowded." The quality of life received high ratings. Ratings 
showed no appreciable decline from January to August, and no substantial differences between supporters and opponents.

The findings indicate that respondents' support or opposition to the nuclear power plant may depend to a large degree on the effects they expect it to have on the community. Attitudes may signal subsequent impacts of the nuclear plant such as decisions by individuals to leave or stay in Hartsville. As part of a longitudinal study of Hartsville, these findings on subjective responses to the nuclear plant provide a context for understanding its future impacts. 


\section{INTRODUCTION}

This report presents the results of a survey of citizens perceptions of the nuclear power generating facility that the Tennessee Valley Authority (TVA) is constructing near Hartsville, Tennessee. The survey was conducted in August and September 1975 as part of a research project on the social impacts of the proposed nuclear plant.

The present survey, the second of two, is called the August Survey to distinguish it from a similar survey conducted in January and February 1975 among the same residents of the Hartsville area. We refer to the earlier survey as the January Survey. ${ }^{2}$ Both surveys were conducted while the Hartsville plant was in its planning and prelicensing phases. We hope to examine social impacts that occur throughout the life-cycle of an energy-generating facility, including construction, the transition from construction to operation, stable operation, and decommissioning.

The following section describes the purposes of the August Survey, its place in the program of research on the social impacts of energy-generating facilities, and the plan of the report.

\subsection{Purposes of the August Survey}

The August Survey addresses two general questions concerning subjective responses to the Hartsville nuclear plant. The first question is: What factors are related to favorable. or unfavorable attitudes toward the facility? Attitudes are here defined as. individual reactions to a specific object. Attitudes include two components: emotional responses to the object and beliefs about it. ${ }^{3}$ for example, a resident of Hartsville may be favorable toward the proposed nuclear power plant (emotional response), and expect it to provide jobs (belief). Research evidence suggests that attitudes can affect other types of behavior. ${ }^{4}$

The second question is: How do residents of the Hartsville area perceive the quality of life, and how have their perceptions changed since January?" "Quality of life" refers to "...the quality of the environment in which people find themselves..."5 "Quality of life" also refers to a person's general satisfaction with life or general well-being. ${ }^{6}$ our 
purpose is to examine changes in the perceived quality of life associated with the nuclear facility planned for Hartsville.

\subsubsection{Factors related to attitudes toward the nuclear facility}

In light of the current national controversy over nuclear energy, ${ }^{7}$ it is important to understand attitudes toward nuclear power plants. A poll by Louis Harris and Associates in March 1975 found that $63 \%$ of a national sample favored the construction of more nuclear plants in the U.S. while $19 \%$ were opposed and 18\% expressed no opinion. ${ }^{8}$ Asked if they would favor construction of a nuclear plant in their nwn rommunity, 54\% said "yes," $24 \%$ "no," and 22\% expressed no opinion. Those who favor the construction of nuclear plants even in their own community seem to comprise a majority.

Although opponents of nuclear energy represent a minority, their attitudes have been sufficiently intense to produce actions of national consequence. An article written late in 1975 pointed to bills before Congress and 24 state legislatures to "slow the spread of nuclear power." 9 Alvin Weinberg has argued that public acceptance is " the most critical question concerning the future of nuclear energy." 10 In the case of Hartsville, the January survey indicated that about $65 \%$ favored construction of the plant, while $25 \%$ opposed it and $10 \%$ expressed no opinion. ${ }^{11}$ These views were assessed nearly two years before the beginning of construction of the plant.

In our hypotheses about factors related to attitudes, we focused on attitudes toward issues related to the nuclear plant, expectations about its effects, information about the plant, and respondents' demographic characteristics.

Attitudes toward related issues. Because the nuclear plant is a project of the TVA, we expected that attitudes toward the proposed plant would be consistent with ratings of TVA's performance. This hypothes is is based on research in social psychology, which indicates that people strive for agreement among their attitudes. 12

A second issue concerns the fact that the proposed facility is a nuclear plant. We assumed that the effects of a nuclear plant might be different from the effects of an equivalent, non-nuclear development 
because of the special characteristics of nuclear plants (e.g., radioactive fuel, the necessity for special safety precautions, concern over accidents, and so on). To examine this assumption, we measured attitudes toward construction of a facility at the same site that would burn coal instead of using nuclear fuel.

Anticipated effects of the nuclear plant. We assessed respondents' beliefs about events likely or unlikely to accompany the nuclear plant. We hypothesized that attitudes would be more favorable to the extent that effects seen as desirable (benefits) were also seen as likely and effects seen as undesirable (costs) were seen as unlikely. These hypotheses derive from research concerning "expectancy theory," which has received strong empirical support. ${ }^{13}$

Using a similar approach in the January survey, we found that attitudes toward the nuclear plant were more favorable to the extent that increases in business and economic growth were seen as likely. Hazards were generally seen as unlikely but attitudes were. less favorable to the extent that hazards to safety were seen as relatively likely. Although proponents of the plant viewed disruptive effects of crowding as less likely than did the opponents, most respondents saw such effects as "likely." This finding suggested a "tradeoff." Supporters of the plant appeared willing to tolerate some disruption of the community by a project they saw as bringing economic benefits. ${ }^{14}$ Our procedures in the August survey included modifications in procedures intended to improve our ability to account for attitudes in terms of anticipated effects. ${ }^{15}$

Information about the nuclear plant. We hypothesized that opponents of nuclear facilities would be better informed about nuclear facilities than supporters on the assumption that opponents may have a greater emotional investment ${ }^{16}$ in their opinion and make a greater effort to find information. We expected supporters to rely on sources of information favorable to the facility, such as TVA, while we expected opponents to seek out sources consistent with their own views. ${ }^{17}$

Demographic characteristics. Demographic characteristics include such factors as sex, race, occupation, and education. Consistent with the findings of the 1975 Harris pol118 and other research, ${ }^{19}$ we expected that 
compared with men, women would show less favorable attitudes toward the nuclear plant. ${ }^{20}$ We also expected that people with favorable attitudes would tend to have fewer years of education. 21 The results of the January survey also suggested relatively favorable attitudes toward the nuclear plant among proprietors, managers, salespersons, clerical workers, craftsmen, and foremen, and relatively unfavorable attitüdes among farmers.22 The January survey also indicated relatively favorable attitudes toward the nuclear plant among blacks. ${ }^{23}$

\subsubsection{Indicators of the perceived quality of life}

Our general premise regarding indicators of the quality of life held that the introduction of the large number of workers necessary to construct the nuclear power plant and the accompanying "boom" in development could lower residents' satisfaction with their environment because of noise and congestion. We expected such effects even before construction of the nuclear plant as local businesses expanded in anticipation of the arrival of the construction force. We predicted that compared with ratings made in January, ratings of neighborhoods, community services, and general satisfaction in August would be lower. 24

\subsubsection{The link between attitudes toward the nuclear plant. and perceived quality of life}

We hypothesized that people with unfavorable attitudes toward the. nuclear plant would give lower ratings of the quality of life than would peuple with favorable attitudes. Our rationale for this hypothesis holds that opponents of the plant will be most sensitive to its adverse effects.

\subsection{The Place of the August Survey in the Social Impact Analysis}

The August survey is part of a larger program of basic research by the Social Impact Analysis Group at Oak Ridge National Laboratory designed to investigate the social effects of different types of energy-generating facilities throughout their life-cycles. 25 The main goals of the program of research are: (a) development of techniques for assessing social and psychological 26 effects of large-scale developments, such as the Hartsville 
power plant; (b) synthesis of data into a theory of social impacts; and (c) investigation of possibilities for minimizing "adverse impacts."

The August survey provides data for the development of theory. It also examines the effects of the nuclear plant on residents' subjective experience, which could include "adverse" effects that require further attention. As a source of data for the development of theory, the August survey stands to contribute to the limited empirical knowledge about social impacts. 27 0nly rarely have studies of social impact systematically investigated the subjective responses of individuals, as in the August survey.

Subjective responses to the proposed nuclear plant may be studied during the pre-construction phases of the Hartsville plant, when other observable effects on the community may be few. One potential area of impact is residents' expectations regarding the future of their community, which could easily change with the knowledge of a plan to build a large nuclear plant. Subjective responses are important because they may signal other overt impacts. For example, people with unfavorable attitudes toward the nuclear plant may experience stress ${ }^{28}$ as the community expands and some may later move away from Hartsville. Similarly, people with unfavorable attitudes may also participate in organized opposition to the nuclear plant. One of our goals is to determine the extent to which subjective responses signal later actions by individuals and groups.

The use of a survey in August represents the application of a wel1established technique for measuring subjective responses. 29 The survey is one of several methods in the research program. As construction of the plant approaches, data may be collected from local records, by direct observation, and other sources. A version of this plan appears in Table 1.1. It incorporates the philosophy of "multiple operationism, which holds that variables of interest should be measured through several methods, so that the biases of each method can be detected by comparing different measurements of the same phenomenon. 30 
Table 1.1

Major Variables and Techniques in the Analysis of Social Impacts

\begin{tabular}{|c|c|c|c|}
\hline $\begin{array}{l}\text { Phase of Development } \\
\text { of the Power Plant }\end{array}$ & $\begin{array}{l}\text { Level of } \\
\text { Analysis }\end{array}$ & Variables & $\begin{array}{l}\text { Techniques for } \\
\text { Measurement }\end{array}$ \\
\hline \multirow[t]{2}{*}{ Pre-construction } & Individual & $\begin{array}{l}\text { Attitudes } \\
\text { Expectations }\end{array}$ & Survey \\
\hline & & $\begin{array}{l}\text { Perceived Quality } \\
\text { of Life }\end{array}$ & Survey \\
\hline \multirow[t]{7}{*}{ Construction } & Individual & $\begin{array}{l}\text { Attitudes } \\
\text { Expectations }\end{array}$ & Survey \\
\hline & & $\begin{array}{l}\text { Perceived Quality } \\
\text { of Life }\end{array}$ & Survey \\
\hline & & Stress & $\begin{array}{l}\text { Survey } \\
\text { Local Records }\end{array}$ \\
\hline & Group & $\begin{array}{l}\text { Membership } \\
\text { Activities }\end{array}$ & $\begin{array}{l}\text { Survey } \\
\text { Local Records }\end{array}$ \\
\hline & Community & $\begin{array}{l}\text { Land-use } \\
\text { Construction } \\
\text { Use of Farilities }\end{array}$ & Ubservation \\
\hline & & $\begin{array}{l}\text { Business increases } \\
\text { Public Budget }\end{array}$ & Local Records \\
\hline & & Migration & $\begin{array}{l}\text { Survey } \\
\text { Local Records }\end{array}$ \\
\hline Operation & \multicolumn{3}{|c|}{ (same variables and techniques as during construction) } \\
\hline Decommissioning & \multicolumn{3}{|c|}{$\begin{array}{l}\text { (same variables and techniques as during pre-construc- } \\
\text { tion phase.) }\end{array}$} \\
\hline
\end{tabular}

Integral to the project is a longitudinal perspective. For example, we administered both the January and August survey to the same group of individuals. (The result is called a "panel design," which allows the assessment of changes in residents' responses. ${ }^{31}$ such a proccdure allows the investigation of impacts that develop over a relatively long period of time.) 


\subsection{Plan of the Report}

To provide background for the August survey, the report first describes the town of Hartsville, TVA's plans for the nuclear plant, and the history of the project. The next section outlines the procedures used in conducting the August survey. In describing the results, we first present the data on attitudes toward the facility and on their relationship with attitudes toward related issues, anticipated effects of the plant, information about it, and demographic characteristics. Next, we present data on the perceived quality of life and its relation to attitudes toward the nuclear plant. The last section discusses some of the potential impacts of the Hartsville nuclear plant and examines theoretical and practical implications of the findings. Notes and references appear at the end of the report.

\section{THE COMMUNITY AND THE NUCLEAR POWER PLANT}

This section provides background on the community of Hartsville, plans by the Tennessee Valley Authority (TVA) for construction of the nuclear power plant, the history of the TVA project, and TVA's plans for mitigating adverse socioeconomic effects of the power plant.

\subsection{The Community: Hartsville and Trousdale County}

Trousdale County is located in central Tennessee, about 45 miles northeast of Nashville, in the valley of the Cumberland River. The population is about 5,000.32 The county contains 174 square miles consisting mainly of rolling hills. Agriculture provides a major source of livelihood. Farmers in the area grow tobacco, corn, and cattle. The average yearly farm income is $\$ 5,844 .{ }^{33}$

The average Trousdale Countian in 1970 was 47 years of age. ${ }^{34}$ Data from 1973 indicate an average of 10.6 years of education. ${ }^{35}$ The January survey suggested that about $50 \%$ of the residents from the county had lived in the county for more than 30 years, and that the average resident had lived at the same address for 13 years. ${ }^{36}$

Hartsville is the only town in Trousdale County, with a population of about 2,500. About 1,200 Hartsvillians work in factories which manufacture textiles, clothing, paper products, and leather goods. The community 
has one radio station, WJKM, and one weekly newspaper, The Hartsville vidette. Hartsville is a center of business and social activity for the surrounding area.

\subsection{TVA and the Nuclear Power Plant}

The Tennessee Valley Authority, a multipurpose resource agency and corporate arm of the U.S. federal government, generates electrical power for an area of about 80,000 square miles, including parts of seven southeastern states. The TVA system currently operates 12 fossil-fueled electric plants, 30 hydroelectric plants, and one nuclear plant. Three other nuclear plants are under construction at this writing - Bellefonte, Sequoyah, and Watts Bar.

In July 1974, TVA applied for a license from the Atomic Energy Commission (AEC) to construct a nuclear plant near Hartsville. ${ }^{37}$ According to the Nuclear Regulatory Commission (NRC), Final Environmental Statement, 38 the proposed plant is intended to supply power to meet projected demands during the 1980's. The choice of nuclear power was based on estimates of the costs of alternative sources of energy. The site near Hartsville was selected from four possible sites on the basis of "...engineering, economic, and environmental factors...," such as the proximity of water, the cost of land, access by highways, requirements for power lines, and so on. 39

The site for the plant, shown in Fig. 2.1, occupies 1,940 acres of prime agricultural land in Trousdale and Smith Counties, bordering on the Cumberland River. The site is five miles from Hartsville.

The power plant is designed to contain four nuclear reactors of the boiling-water type. The cost was estimated at $\$ 2.15$ billion, 40 but more recent estimates place it at $\$ 2.5$ billion. Each reactor is designed to produce 3,579 megawatts (therma1) to generate 1,205 megawatts of electrical power, requiring 27,000 tons of uranium to operate at $80 \%$ capacity for 30 years. The expected life of the facility is about 35 years. ${ }^{41}$

The original timetable for construction allowed eight years for completion of the four reactors but it may take longer. Completion of the first was planned after five years. ${ }^{42}$ Early phases of construction wi11 require about 1,100 workers. Peak construction wil1 require approximately 5,300 workers. After the plant is completed about 350 workers will be required to operate it. 43 


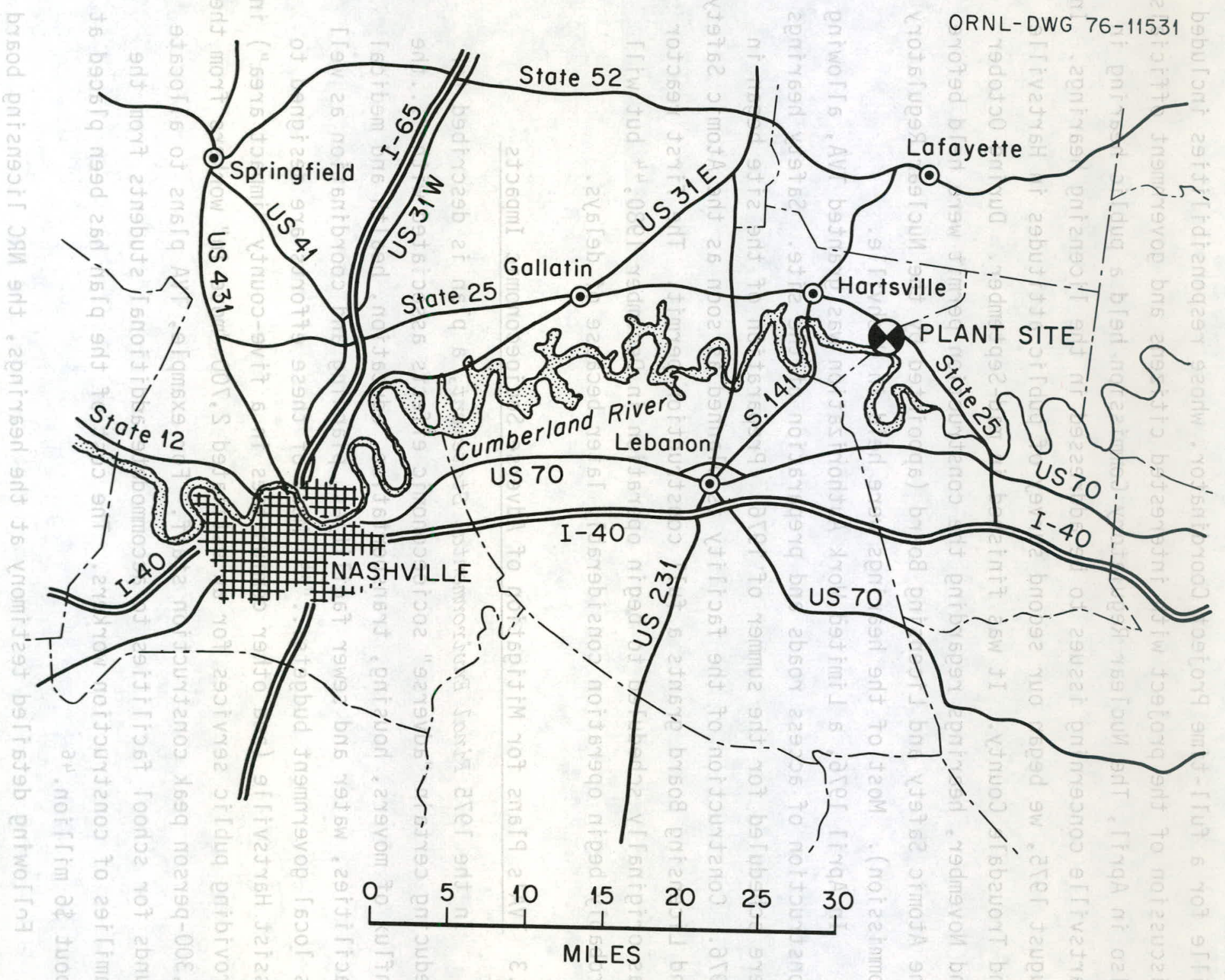

6

Fig. 2.1. Map of the Hartsville area showing the site of the nuclear plant. 
Seven months after TVA applied for a construction permit, the January survey was conducted (1975). In April 1975, TVA opened an office in Hartsville for a full-time Project Coordinator, whose responsibilities included discussion of the project with interested citizens and government officials. Also in April, The Nuclear Regulatory Commission held a public hearing in Hartsville concerning issues to be addressed in the licensing hearings. In August 1975, we began our second survey of public attitudes in Hartsville and Trousdale County. It was finished in mid-September. During October and November, hearings regarding the construction permit were held before the Atomic Safety and Licensing Board (appointed by the Nuclear Regulatory Commission). Most of the hearings were held in Nashville.

In April 1976, a Limited Work Authorization was granted TVA, allowing construction of access roads and preparation of the site. Safety hearings were scheduled for the summer of 1976. Preparation of the site began in - 1976. Construction of the facility is planned as soon as the Atomic Safety and Licensing Board grants a full construction permit. The first reactor was originally scheduled to begin operation in December 1980,44 but will probably begin operation considerably later because of delays.

\subsection{TVA's Plans for Mitigation of Adverse Socineconomic Impacts}

In the 1975 Final Environmental statement, a plan is described for reducing certain "adverse" socioeconomic effects associated with "...the influx of movers, housing, transportation, education, health and medical facilities, water and sewer facilities, planning and coordination as well as local government budgets..."155 Most of these efforts are designed to assist Hartsville (and other communities in a five-county "impact area") in providing public services for an estimated 2,700 "move in" workers from the 5,300-person peak construction staft. For example, TVA plans to allocate funds for school facilities to accommodate additional students from the families of construction workers. The cost of the plan has been placed at ahout. $\$ 6$ million. 46

Fnllowing detailed testimony at the hearings, the NRC licensing board conditioned TVA's Limited Work Authorization to include TVA's proposed mitigation plan as well as two additional NRC staff proposals requiring 
monitoring, evaluation, and reporting of the effectiveness of the mitigation plan on a semi-annual basis during construction and until 18 months after the last operating license is issued. 47

In summary, TVA plans a nuclear power plant that will occupy a site of nearly 2,000 acres, about five miles outside Hartsville, Tennessee, a town of 2,500. Construction would require up to 5,300 workers. TVA plans to monitor and alleviate some of the direct, adverse effects of the influx of workers. With this background, we next describe our procedures in surveying residents' views about the facility in August 1975.

\section{METHODS USED IN COLLECTING AND ANALYZING THE DATA}

\subsection{Design}

In a "panel design," 148 we re-interviewed in August 1975, members of a sample of 350 residents of Hartsvilie and Trousdale County whom we interviewed in January 1975.

\subsection{Procedures}

\subsubsection{Sampling procedure}

In selecting respondents for the January 1975 survey, a simple random sample was drawn, allowing every adult resident of the county an equal chance of selection. To list the adult residents of the county, we began with two published directories. 49 With the help of the local interviewers, we updated the list by deleting those who had moved or died, and adding new members of households and people who had recently moved into a neighborhood. The final list contained the names of approximately 3,600 residents of Trousdale County over the age of 18 years. We assumed our list approximated an exhaustive list of the residents of the county over the age of 18 years.

For the January survey, 375 respondents and 75 alternates were randomly selected. We contacted 422 people to obtain a sample of 350 participants (21 were unable to arrange an appointment and 51 refused to participate; these 72 people were replaced with alternates.) 50 
For the August survey, we attempted to contact a 11350 of the original sample; $81 \%$ of them, or 288 people, participated in the August survey. (Eight of the January participants had moved out of the county, 22 refused to be re-interviewed, and we were unable to contact 32).51,52 This report is based on the panel of 288 respondents.

\subsubsection{Interviewing procedure}

Local residents served as interviewers, including 17 women and one man recommended by community leaders. Before collection of the data, the interviewers were told the purposes of the study and trained in techniques of interviewing. During data collection, members of the staff remained in Hartsville to supervise and maintain liaison with local officials.

Respondents were first contacted by mail; they received a letter describing the survey, which emphasized that participation was voluntary, and that each participant would be paid for his or her time. Interviewers contacted the respondents a few days later to arrange an appointment for the interview.

In conducting the interviews, the interviewers wrote the responses in the questionnaire. Interviews lasted about an hour. A few weeks later respondents received checks for $\$ 5.00$ as payment for their participation.

\subsubsection{The questionnaire}

Most of the questions included in the survey concerned five topics:

1. Background characteristics, such as sex, age, and occupation;

2. Perceptions regarding the "quality of life" in the community, including characteristics of neighborhood and satisfaction with services;

3. Knowledge and sources of information about the nuclear facility;

4. Anticipated changes in the community that might accompany the nuclear facility, including the estimated likelihood of the changes and their desirability for the respondent; and

5. Favorability toward the facility--the extent to which respondents favor or oppose it. 
A procedure was introduced in the August survey to guard against biases that might affect answers to sensitive questions. Respondents wrote their responses to some questions in private instead of saying them aloud. Answer sheets were sealed in an envelope and returned to the interviewer. The questions concerned ratings of TVA's performance, favorability toward construction of the nuclear facility, and favorability toward construction of a similar facility that burned coal. 53

\subsection{Characteristics and Representativeness of the Respondents}

Most respondents in August were reared in rural areas (71\%) or sma 11 towns (22\%). ${ }^{54}$ Approximately one-half had lived in the county for more than 30 years. Most were married (79\%). The average respondent was 46.6 years of age and had completed 11.7 years of school.

The original sample of 350 was randomly selected so that it would be representative of the adult population of Trousdale County. However, some people refused to participate or could not be located in January. The same was true in August. The loss of these people could affect the representativeness of the panel. Especially important is the problem of respondents' education. A recurring finding in survey research is that people with relatively few years of education tend to be among the most likely to refuse to participate. ${ }^{55}$ In a random sample with a sizable number of "refusals," respondents may tend to have more years of education than the members of the population. A similar problem confronts the August survey. We found that the "dropouts" from the January to August survey had significantly fewer years of education than the 288 respondents. 56

We had no current data on the characteristics of the population of Trousdale County against which to evaluate the representativeness of our panel in terms of education, but we could make an approximate assessment by using a 1973 report from the Office of Comprehensive Health Planning in Nashville. The report gives a median of 8.4 years of education for the state and 10.6 years for Trousdale County (for persons 25 years of age and older). ${ }^{57}$ The median among respondents to the January survey was 11.0 years; the median for the August survey was 11.7 years. Thus, the average respondent in August may have had about one more year of education than 
the average Trousdale Countian. By implication, if the data on education from 1973 are still valid in 1976, the findings of the August survey may not be generalizable to residents of Trousdale County with relatively few years of education.

For an approximate evaluation of the representativeness of the panel in terms of other characteristics; we used the 1970 Census $^{58}$ as a source of data on the residents of Trousdale County. The average respondent in the August survey was 46.6 years old, compared with an average age of 46.9 years in the county in 1970.59 of 288 respondents in August, $52 \%$ were women; the corresponding figure in the Census was $52 \%$. Only $10 \%$ of the respondents in August were black, compared with $14 \%$ in the county in 1970 . Respondents in August may have contained about $4 \%$ fewer blacks than the population. The two potential limitations on the representativeness of the panel - concerning education and race - assume that data on Trousdale County from 1970 and 1973 were still approximately correct in 1975 .

\subsection{Analysis of the Data}

To preserve the anonymity of the respondents, each was identified only by a five-digit number. Responses to all questions in the questionnaire were coded using written instructions for classifying resporises. The data were placed on cumputer cards and analyzed through use of standard statistical programs. 60

Statistical analyses are based on the panel of 288 people who were interviewed in both January and August. Besides such descriptive procedures as frequency distributions, three types of analyses were conducted. First, we examined changes in the average response from January to August. Second, we assessed the consistency of individual responses, which refers to the predictability of a person's response in August frum his or her response in January. ${ }^{61}$ The third and primary form of analysis involves

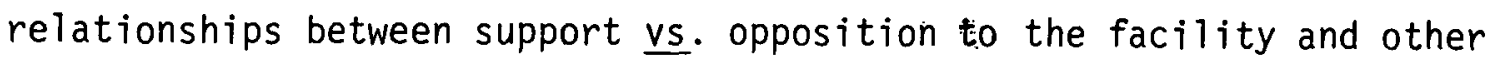
factors, including attitudes toward related issues, anticipated effects, information, demographic characteristics, and perceived quality of life. The next four sections of this report describe the results of the survey. 


\section{SUPPORT VS. OPPOSITION TO THE NUCLEAR POWER PLANT AND ATTITUDES TOWARD RELATED ISSUES}

\subsection{Favorability Toward the Nuclear Plant}

In assessing respondents' favorability toward the proposed plant, we asked two questions. The one we considered most important was, "If it were up to you, would you permit construction of the TVA power plant near Hartsville?" A second question asked respondents to indicate how close to their homes they would permit the plant to be built. The following discussion presents the distribution of favorable and unfavorable views, their consistency from January to August, and the agreement among answers to questions designed to measure attitudes.

\subsubsection{Distribution of support and opposition of the facility}

Of the 285 respondents who answered the question of whether they would permit the plant to be built, 69\% said "definitely yes" or "probably yes."62 For brevity, we designate these people as "supporters" of the nuclear facility. The remaining respondents - $31 \%$ - said they would "definitely" or "probably" not permit construction of the plant. We call these people "opponents." Only three people, or $1 \%$ of all 288 respondents, declined to answer the question.

The distribution of responses in January and August appears in Table 4.1. In January, $62 \%$ of the 276 members of the panel who answered the question were supporters, $11 \%$ said they did not know, and $27 \%$ were opponents. ${ }^{63}$ In August we found more supporters (69\%) and more opponents (31\%), among the 285 people who answered, probably because the "don't know" category was not included in August. Although more respondents expressed a favorable or unfavorable opinion in August, fewer declined to answer the question (12 did not answer in January, compared with three in August). 64 The lack of a "no opinion" category in August may have prompted some people who were neutral to take a position. The data may reflect the division of opinion in the panel under conditions of a "forced choice," but may distort the views of respondents whose position is close to neutral. We estimate that $69 \%$ and $37 \%$ are upper bounds of the proportions of support and opposition. 
(If we consider the responses in January excluding the "don't know" category, the proportions of support and opposition are $70 \%$ and $30 \%$, almost the same as the proportions in August under conditions of "forced choice.") In brief, results indicate that supporters outnumbered opponents by about two to one.

Table 4.1

Distribution of Responses in January and August to the Question, "If it were up to you, would you permit construction of the TVA power plant Near Hartsville?"

(Excluding people who did not answer)

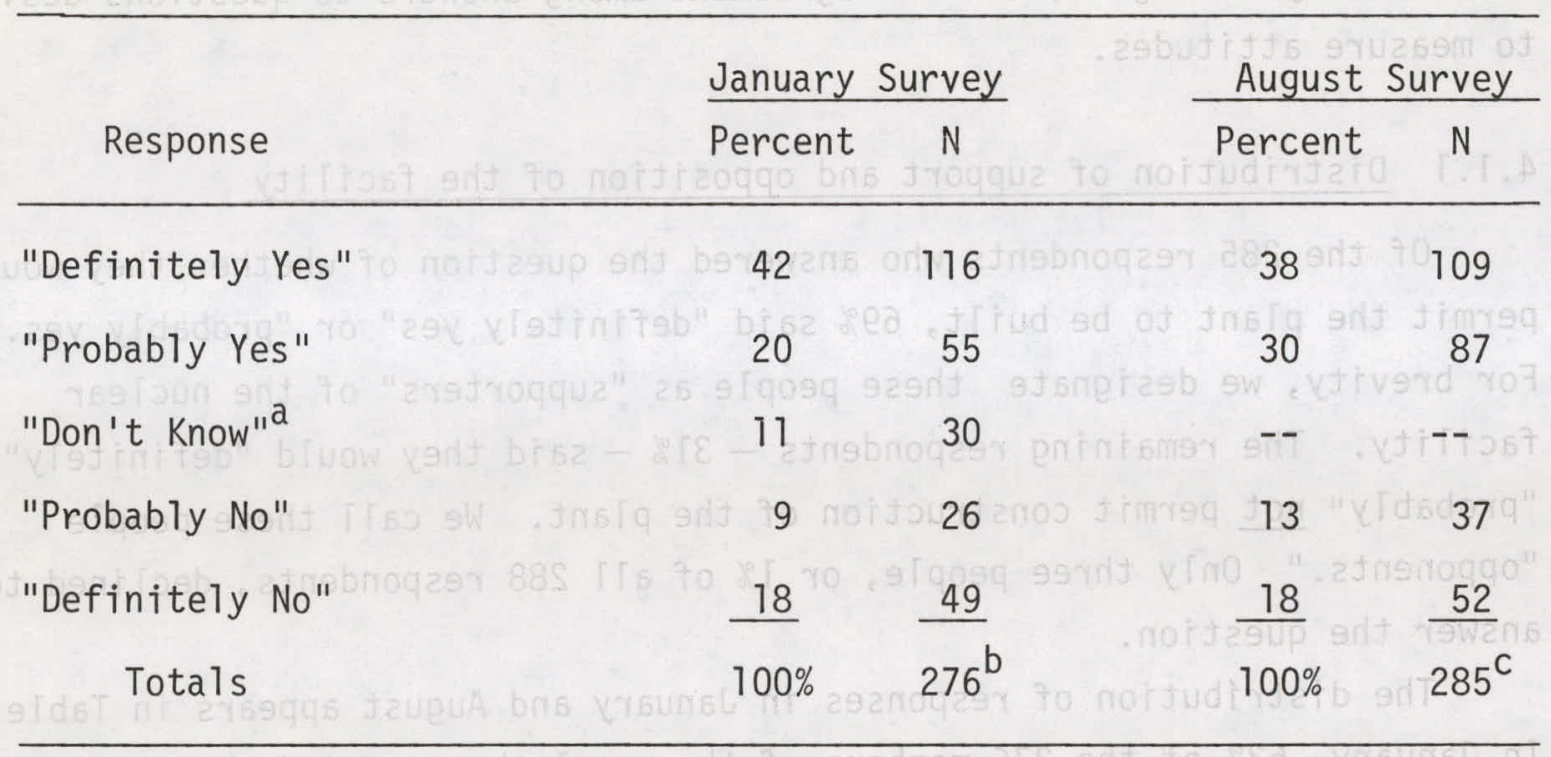

a The "don't know" alternative was present only in the January survey and not in August.

b In January, 12 people left the question unanswered.

${ }^{\mathrm{C}}$ In August, three people left the question unanswered.

\subsubsection{Consistency of responses from January to August}

To examine the consistency of individuals' responses in August with their responses in January, we calculated a statistical index, the Pearson product moment correlation coefficient. 65 The Pearson $\underline{r}$ was $.76(p<.01)$, indicating a high degree of consistency. As shown in Table 4.2, 163 persons ( $57 \%$ of the respondents) made the same response in August as in 
Table 4.2

Consistency from January to August in Responses to the Question,

"If it were up to you, would you permit construction

of the TVA power plant near Hartsville?"

(Including people who did not answer)

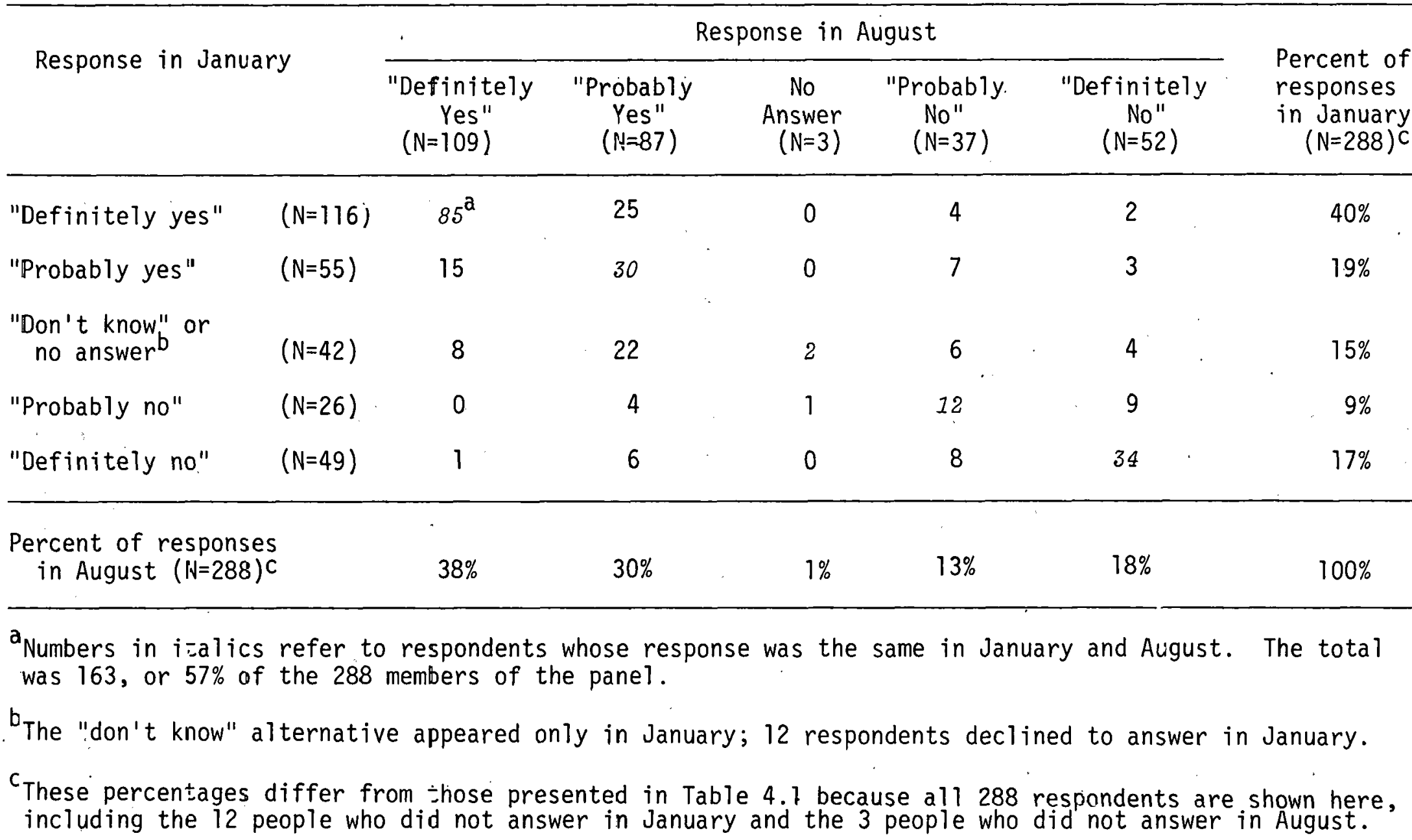


January. A total of 125 people changed their responses. Of 40 "changers" who said "don't know" or did not respond in January, 30 shifted to "yes" and 10 shifted to "no" in August. Of the other 85 people whose responses changed, most (57) answered either "yes" or "no" in both January and August, but took a moderate position at one time and an extreme position at the other time. Only 27 people, or $10 \%$ of 211 respondents, changed from supporter to opponent or vice versa. (The distribution of people who changed their response to the "permit construction" question is summarized in Table 4.3.) Of the panel of 288 , a total of 218 people, or $76 \%$, were consistently classified as supporters or opponents in both January and August. In brief, despite the changes in the format of the question, responses of individuals remained quite consistent in terms of direction (favorable vs. unfavorable) and were only slightly less consistent in terms of extremity ("probably" vs. "definitely"). The implication is that support or opposition to the nuclear plant was consistent from January to August.

Table 4.3

Distribution of Respondents whose Answer to the "Permit Construction" Question Changed from January to August

\begin{tabular}{|c|c|c|}
\hline Type of Change & $\begin{array}{l}\text { Number of } \\
\text { Respondents }\end{array}$ & $\begin{array}{l}\text { Percent of al1 } \\
\text { Respondents } \\
(\mathrm{N}=288)\end{array}$ \\
\hline $\begin{array}{l}\text { Consistent support but shift from } \\
\text { "definitely" to "probably" or } \\
\text { "probably" to "derinftely" }\end{array}$ & 40 & 14 \\
\hline $\begin{array}{l}\text { Consistent opposition but shift } \\
\text { from "definitcly" to "probably" } \\
\text { or "probably" to "definitely" }\end{array}$ & 17 & 6 \\
\hline $\begin{array}{l}\text { Shift from "don't know" (or no } \\
\text { answer) to support }\end{array}$ & 30 & 10 \\
\hline $\begin{array}{l}\text { Shift from "don't know" (or no } \\
\text { answer) to opposition }\end{array}$ & 10 & 3 \\
\hline Shift from support to opposition & 16 & 6 . \\
\hline Shift from opposition to support & 11 & 4 \\
\hline Shift from opposition to no answer & $\frac{1}{10 r}$ & $\underline{0}$ \\
\hline Totals & 125 & $43 \%$ \\
\hline
\end{tabular}


4.1.3 Consistency among responses to different questions about attitudes toward the nuclear plant

As a second measure of respondents' attitudes toward the nuclear plant, the August survey included a question in which respondents indicated how close to their homes, in miles, they would allow the plant to be built. This question reflects the frequent use of physical distance as an indicator of attitudes. ${ }^{66}$ Close proximity is thought to show a favorable attitude; the larger the distance, the more intensely negative the attitude. ${ }^{67}$

The question about "distance from home" was open-ended and elicited responses from one-fourth mile to 25,000 miles. Responses appear in Table 4.4. We interpreted a response of less than five miles as showing a favorable attitude. It means that a location near or within Hartsville is acceptable. (The actual site is five miles from Hartsville.) We interpreted a response of 6 to 19 miles to mean that a more remote site in the county would be preferable and that the respondent's view was only moderately favorable. We interpreted a response of 20 to 99 miles to indicate that the location of the plant in Trousdale County is unacceptable; such a response probably reflects an unfavorable attitude toward the nuclear plant. We interpreted a response of greater than 100 miles as an indication of an intense, negative attitude toward the plant (the choice of 100 miles was arbitrary).

To assess consistency of responses to the "distance from home" and the "permit construction" questions, we calculated the correlation coefficient. It was .65 ( $p<.01)$, indicating a strong relationship between individual responses to the two questions. Table 4.3 shows the relationship. Respondents who were "supporters" gave smaller distances than did "opponents." Respondents who "definitely" opposed construction gave the largest distances. We also examined the consistency of responses to the two questions about attitudes in the August survey and two questions about attitudes in January.

The "permit construction" question was the same in both January and August. In January, we also asked, "In general, do you think the proposed power plant will be a good thing for Hartsville or not?" Respondents could answer "definitely a good thing," "probably a good thing," "unsure," "probably not a good thing," or "definitely not a good thing." We interpreted the response as an indication of favorability toward the nuclear plant. As 
Table 4.4

Responses so tre Question, "If you could decide where the plant were to be located, how close to your home in miles, would you permit it to be built?' and their relaticnship with responses to the "Permit Construction" Question

\begin{tabular}{|c|c|c|c|c|c|c|}
\hline \multirow[b]{2}{*}{ Response } & & \multicolumn{4}{|c|}{ Response to the "Permit Construction" Question } & \multirow[b]{2}{*}{$\begin{array}{r}\text { Percent of } \\
\text { Responses } \\
(N=261)\end{array}$} \\
\hline & & $\begin{array}{c}\text { 'Jefinitely } \\
\text { yes" } \\
(N=99)\end{array}$ & $\begin{array}{c}\text { "Probably } \\
\text { yes" } \\
(N=81)\end{array}$ & $\begin{array}{c}\text { "Probably } \\
\text { no" } \\
(N=36)\end{array}$ & $\begin{array}{c}\text { "Definitely } \\
\text { no" } \\
(\mathbb{N}=45)\end{array}$ & \\
\hline Less than 4 miles & $(N=40)$ & 30 & 9 & 1 & 0 & 15 \\
\hline 4 to $\bar{j}$ miles ${ }^{a}$ & $(N=79)$ & 53 & 20 & 2 & 4 & 30 \\
\hline 6 to 19 miles & $(N=38)$ & 15 & 18 & 3 & 2 & 15 \\
\hline 20 to 99 miles & $(N=37)$ & 1 & 19 & 10 & 7 & 14 \\
\hline 100 miles or more ${ }^{b}$ & $(N=67)$ & 0 & 15 & 20 & 32 & $\frac{26}{100}$ \\
\hline Median distance ${ }^{c}$ & & $5 \mathrm{mi}$. & $.0 \mathrm{mi}$. & $200 \mathrm{mi}$. & $1, \mathrm{COO} \mathrm{mi}$ & \\
\hline
\end{tabular}

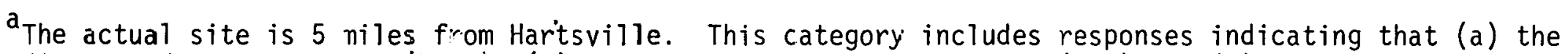
distance does not matter $i N=21)$. (b) the present site is acceptable $(N=8)$, or (c) the present site is acceptable under a specified condition $(\mathrm{N}=14)$.

bIncluded in this catejory are responses incicating "as far as possible" or "would not permit" ( $N=26$ ).

${ }^{\mathrm{C}}$ The rumber of miles such that $50, \%$ of resfordents indicated a smaller distance. 
shown in Table 4.5, responses to the two questions in January were highly correlated. Responses to the two questions about attitudes in August were highly correlated with each other and with responses to both questions about attitudes in January. In brief, the results indicate that attitudes fluctuated little between the two surveys, and different ways of measuring the attitudes produced similar results.

- Table 4.5

Consistency Among Responses to Questions Used to Measure Attitudes Toward the Nuclear Plant

\begin{tabular}{|c|c|c|c|c|}
\hline \multirow[b]{2}{*}{ Question } & \multicolumn{4}{|c|}{ Pearson Correlation Coefficient } \\
\hline & $\begin{array}{c}\text { "Permit } \\
\text { Construction" } \\
\text { (January) }\end{array}$ & $\begin{array}{c}\text { "Good for } \\
\text { Hartsville" } \\
\text { (January) }\end{array}$ & $\begin{array}{c}\text { "Permit } \\
\text { Construction" } \\
\text { (August) }\end{array}$ & $\begin{array}{l}\text { How far } \\
\text { from Home" } \\
\text { (August) }^{b}\end{array}$ \\
\hline $\begin{array}{l}\text { "Permit construction" } \\
\text { (January) }\end{array}$ & -- & & & \\
\hline $\begin{array}{l}\text { "Good for Hartsville" } \\
(\text { January) }\end{array}$ & $\begin{array}{l}84^{\star \star} \\
(N=268)\end{array}$ & --- & & \\
\hline $\begin{array}{l}\text { "Permit construction" } \\
\text { (August) }\end{array}$ & $\begin{array}{l}.76 * \star \\
(N=275)\end{array}$ & $\begin{array}{l}70 * \star \\
(N=277)\end{array}$ & --- & \\
\hline $\begin{array}{l}\text { "How far from home" } \\
\text { (August) }\end{array}$ & $\begin{array}{l}.60 * \star \\
(N=253)\end{array}$ & $\begin{array}{l}58 * \star \\
(N=255)\end{array}$ & $\begin{array}{l}71 * * \\
(N=261)\end{array}$ & -- \\
\hline
\end{tabular}

apearson $\underline{r}^{\prime} s$ are for the variable in column with the variable in row.

${ }^{b}$ scaled from 1 to 5 , using the categories in Table 4.3.

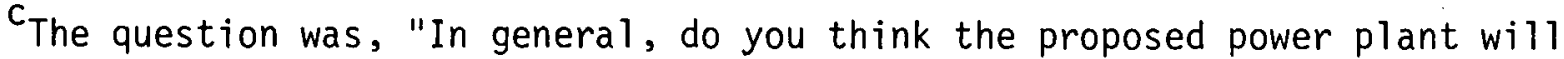
be a good thing for Hartsville or not?"

$\star \star p<.01$

\subsection{Attitudes Toward TVA's Performance}

To assess respondents' attitudes toward TVA's performance, we asked them to rate the job TVA was doing. As shown in Table $4.6,87 \%$ of the panel thought TVA was doing "average" or better. In January, the corresponding figure was $88 \%$. The distributions of responses in January and August were nearly identical. To assess the consistency of attitudes toward 
TVA from January to August, we calculated a correlation coefficient; it was $.54(p<.001, N=264)$, indicating a reasonable degree of consistency.

Because TVA is constructing the nuclear plant, we expected supporters of the facility to give TVA relatively high ratings on performance. As shown in Table 4.6, supporters of the plant did give TVA somewhat higher ratings than did opponents, but most opponents (74\%) still gave TVA "average" or higher ratings. In August, the correlation between ratings of TVA's performance and attitudes toward the plant was moderate but significant $(r=.43, N=280, p<.001)$. This finding agrees with our predictions, but too many opponents gave TVA favorable ratings for us to interpret the evidence as support for the idea that people maintained consistent. attitudes toward the nuclear plant and TVA.

Table 4.6

Responses to the Question, "In general, how good a job do you think TVA is doing?"

\begin{tabular}{|c|c|c|c|c|c|c|}
\hline Response & \multicolumn{2}{|c|}{$\begin{array}{l}\text { Whole Panel in } \\
\text { January }(N=266) \\
\frac{\text { Percent } N}{N}\end{array}$} & \multicolumn{2}{|c|}{$\begin{array}{l}\text { Whole Panel in } \\
\text { August }(\mathrm{N}=281) \\
\text { Percent } N\end{array}$} & $\begin{array}{l}\text { Percent of } \\
\text { Supportersa in } \\
\text { August }(N=194)\end{array}$ & $\begin{array}{l}\text { Percent of } \\
\text { Opponents in } \\
\text { (August }(N=86)\end{array}$ \\
\hline "[xce]lent" & 17 & 46 & 15 & 41 & $1 \bar{g}$ & 6 \\
\hline "Good" & 47 & 124 & 44 & 123 & 48 & 35 \\
\hline "Average" & 23 & 62 & 29 & 83 & 27 & 33 \\
\hline "Below Average" & 5 & 14 & 3 & 8 & 2 & 5 \\
\hline "Poor" & 8 & 20 & 9 & 20 & 4 & 22 \\
\hline Totals & 100 & 266 & 100 & 281 & 100 & $101^{b}$ \\
\hline $\begin{array}{l}\text { Favorable } \\
\text { Ratings } \mathrm{C}\end{array}$ & 87 & 232 & 88 & 247 & 94 & 74 \\
\hline
\end{tabular}

"Supporters of the proposed nuclear facility - those who answered "yes" to the "permit construction" question.

$\mathrm{b}_{\mathrm{Figures}}$ were rounded to the nearest percent.

"Favorable" means "average" or better. 


\subsection{Attitudes Toward a Coal-burning Plant Instead of a Nuclear Plant}

Respondents' attitudes toward the nuclear plant may reflect their beliefs about nuclear plants. On the other hand, respondents may have the same attitudes toward any large-scale development in the area. To examine this issue we asked, "Suppose the power plant planned for Hartsville was going to burn coal instead of using nuclear fuel. If it were up to you, would you permit construction of this type of plant?" (This question was new to the August survey.) Table 4.7 shows the responses. About $30 \%$ of the respondents said they would oppose a coal-fired plant, nearly the same as the proportion of the panel who opposed the nuclear plant $(31 \%)$. However,

Table 4.7

Relationship Between Support vs. Opposition to the Nuclear Plant and Support vs. Opposition to Coal-Burning Plant Instead of a Nuclear Plant

\begin{tabular}{|c|c|c|c|c|c|c|}
\hline \multirow[t]{2}{*}{$\begin{array}{l}\text { Response to Question } \\
\text { about Coal-burning } \\
\text { Plant Instead }\end{array}$} & \multicolumn{2}{|c|}{$\begin{array}{l}\text { Whole Panel } \\
(\mathrm{N}=286)\end{array}$} & \multicolumn{2}{|c|}{$\begin{array}{c}\text { Supporters }{ }^{b} \text { of } \\
\text { the Nuclear Plant } \\
(N=195)\end{array}$} & \multicolumn{2}{|c|}{$\begin{array}{c}\text { Opponents of } \\
\text { the Nuclear Plant } \\
(\mathrm{N}=88)\end{array}$} \\
\hline & Percent & $\mathrm{N}$ & Percent & $\mathrm{N}$ & Percent & $\mathrm{N}$ \\
\hline "Definitely yes" & 20 & 58 & 23 & 45 & 14 & 12 \\
\hline "Probably yes" & 28 & 80 & 32 & 62 & 19 & 17 \\
\hline "Don't know" & 22 & 62 & 23 & 45 & 18 & 16 \\
\hline "Probably no" & 19 & 54 & 16 & 31 & 26 & 23 \\
\hline "Definitely no" & 11 & 32 & $\underline{6}$ & 12 & 23 & 20 \\
\hline Totals & 100 & 286 & 100 & 195 & 100 & 88 \\
\hline $\begin{array}{l}\text { Support }{ }^{\mathrm{C}} \text { for coal- } \\
\text { burning plant }\end{array}$ & 48 & 138 & 55 & 107 & 33 & 29 \\
\hline $\begin{array}{l}\text { Opposition to coal- } \\
\text { burning plant }\end{array}$ & 30 & 86 & 22 & 43 & 49 & 43 \\
\hline
\end{tabular}

${ }^{a}$ The question was, "Suppose the power plant planned for Hartsville was going to burn coal instead of using nuclear fuel. If it were up to you, would you permit construction of this type of facility?"

bersons who answered "definitely yes" or "probably yes" to the question about permitting construction of the nuclear power plant.

"Persons who answered "definitely yes" or "probably yes" to the "permit coal instead" question. 
opponents of a coal plant are not necessarily the same people who oppose the nuclear plant. As shown in Table 4.7, supporters of the nuclear plant were more favorable toward the coal plant than were opponents of the nuclear plant. Attitudes toward the two types of facilities were significantly correlated $(r=.35, N=284, p<.001)$, although the correlation was modest.

The largest fraction of the panel would support both types of plant (107 people, or $38 \%$ of the 283 who answered both questions). For these people it is unlikely that the differences between nuclear and coal-fired plants were an issue. Similarly, some people opposed both types of plants ( 43 people, or $15 \%$ of those who answered both questions) and may oppose any large-scale development. A few opponents of the nuclear plant would accept a coal plant (29 people). For these $10 \%$, differences between coa $1-$ fired and nuclear plants could be critical to the opposition to the nuclear plant. On the other hand, 43 people (or 15\%) would support a nuclear plant but reject a coal plant. For these people, differences between coal-fired and nuclear plants could contribute to support of the nuclear plant. A total of 61 people said they did not know whether they would support a coal-fired plant; most were supporters of the nuclear plant (45 people or $16 \%$ ) who may have had doubts about a coal-fired plant. The 16 opponents of the nuclear plant who did not know whether they favored a coal plant may also have had reservations about it. However, the absence of an opinion about the coal-fired plant makes it difficult to infer the importance of the differences between the two types of facilities for these people. As summarized in Table 4.8, the data suggest that the differences between nuclear and coal-fired plants may have been a critical component of attitudes toward the proposed nuclear facility for 72 people, or $25 \%$ of the panel. Fur. the majority (75\%), the specific type of facility was apparently only one of several components of attitudes toward the nuclear plant. 
Table 4.8

Attitudes Toward the Proposed Nuclear Plant or a Coal-Burning Facility Instead: How Important is the Use of Nuciear Fuel?

\begin{tabular}{|c|c|c|}
\hline \multirow{2}{*}{$\begin{array}{l}\text { Response to Questions } \\
\text { about Nuclear Plant } \\
\text { or Coal Plant Instead }\end{array}$} & $\begin{array}{c}\text { Distribution of } \\
\text { Responses }\end{array}$ & \multirow{2}{*}{$\begin{array}{l}\text { Inferred Importance of } \\
\text { the Differences Between } \\
\text { Nuclear. Fuel and Coal } \\
\text { for Attitudes Toward a } \\
\text { Nuclear Plant }\end{array}$} \\
\hline & Percent & \\
\hline
\end{tabular}

Support both nuclear and coal-burning plant

Oppose both nuclear and coal-burning plant

Oppose nuclear plant but support coal-burning plant

Support nuclear plant but oppose coal-burning plant

Support nuclear plant; don't know about coalburning plant

Oppose nuclear plant; don't know about coalburning plant

Totals
107

38

10

15

$\frac{16}{283} \quad \frac{6}{100}$

Probably not critical; possibly unimportant

Probably not critical; possibly unimportant

Possibly a critical component of opposition to nuclear plantb

Possibly a component of support of nuclear plantb

Possibly one of several components of support of nuclear plant

Possibly one of several components of opposition to nuclear plant

"Support" means "definitely" or "probably" would permit construction;

"oppose" means "definitely" or "probably" would not permit construction.

beople who oppose one type of plant but not the other type may base their response primarily on characteristics of either type of facility. 


\section{ATTITUDES TOWARD THE NUCLEAR PLANT AS A FUNCTION OF ITS ANTICIPATED EFFECTS}

\subsection{Perceived Likelihood of Potential Effects of the Nuclear Plant}

To assess respondents' perceptions of the likelihood of various effects of the nuclear plant, we asked them to consider 27 events that could conceivably accompany its construction or operation. 68 These potential effects appear in Table 5.1. Respondents were asked to estimate how likely each effect was from seven choices: "certain to happen," "very 1ikely," "likely," "perhaps," "unlikely," "very unlikely," and "almnst. impnssible." This procedure for assessing perceived likelihood of effects of the plant was a modified version of the procedure used in January. 69

\subsubsection{Estimates of the likelihood of effects in August}

As shown in Table 5.1, respondents' average estimates of the likelihood of specific effects of the nuclear plant ranged from 2.1 ("very likely") to 4.6 ("unlikely"). Effects generally seen as "very likely" included traffic congestion, crowded schools, increased noise, shortage of housing, increased business, and meeting of new people. Respondents generally seemed unwilling to rule out any of the effects, Mean estimates of likelihood never reached 5.0 ("very unlikely"), and only three effects had means over 4.0 ("unlikely"). These effects, seen as least likely, included radiation hazard, sabotage at the plant, and cheap electricity.

\subsubsection{Grouping of the potential effects}

To classify the effects into groups, we used a statistical leclinique called factor analysis. 70 This technique identified the groups of effects for which the respondents gave correlated estimates of likelihood. The resulting groups therefore contain effects the respondents see as "going together." Five groups emerged: (1) disruptive effects of population growth, such as traffic congestion and crowded schools; (2) hazards to safety or environment, such as radiation; (3) increases in business and new facilities that might accompany new business, such as stores and billboards; (4) attention from outside of town, including tourism and 
Table 5.1

Perceived Likelihood of 27 Potential Effects of the Nuclear Plant

\begin{tabular}{|c|c|c|c|c|}
\hline Group of Effects ${ }^{a}$ & Effect & $\begin{array}{l}\text { Mean Estimate } \\
\text { of Likelihood }\end{array}$ & $\begin{array}{l}\text { Correlation } \\
\text { of January } \\
\text { with August }\end{array}$ & Group Meanb \\
\hline $\begin{array}{l}\text { Disruptive Effects } \\
\text { of Population } \\
\text { Growth }\end{array}$ & $\begin{array}{l}\text { Traffic congestion } \\
\text { More taverns and bars } \\
\text { Crowding in schools } \\
\text { Increased noise } \\
\text { Increased crime } \\
\text { Drugs in schools } \\
\text { Increased taxesd } \\
\text { Housing shortages }\end{array}$ & $\begin{array}{l}2.1 \\
2.5 \\
2.4 \\
2.5 \\
2.8 \\
2.7 \\
3.1 \\
2.2\end{array}$ & $\begin{array}{l}.23 \star \star \\
.34 \star \star \\
.33 \star \star \\
.31 \star \star \\
.43 \star \star \\
.48 \star \star \\
.20 \star \star \\
--\end{array}$ & $\begin{array}{c}2.5 \\
\text { "likely" }\end{array}$ \\
\hline $\begin{array}{l}\text { Hazards to } \\
\text { Safety and } \\
\text { Environment }\end{array}$ & $\begin{array}{l}\text { Radiation Hazard } \\
\text { Air Pollution } \\
\text { Sabotage at plant } \\
\text { Foggy days } \\
\text { Pollution of lake }\end{array}$ & $\begin{array}{l}4.0 \\
3.5 \\
4.5 \\
3.9 \\
3.5\end{array}$ & $\begin{array}{l}.61 \star \star \\
.46^{\star \star} \\
.40^{\star \star} \\
-- \\
.47^{\star \star}\end{array}$ & $\begin{array}{l}3.9 \\
\text { "perhaps" }\end{array}$ \\
\hline $\begin{array}{l}\text { Increased } \\
\text { Business and } \\
\text { New Facilities }\end{array}$ & $\begin{array}{l}\text { More stores/shoppinge } \\
\text { More public entertainment } \\
\text { More recreation areas } \\
\text { More billboards } \\
\text { Increased business }\end{array}$ & $\begin{array}{l}2.8 \\
3.2 \\
3.1 \\
3.4 \\
2.5\end{array}$ & $\begin{array}{l}-- \\
.33 * \star \\
-- \\
-- \\
.33 * \star\end{array}$ & $\begin{array}{c}3.0 \\
\text { "1ikely" }\end{array}$ \\
\hline $\begin{array}{l}\text { Attention from } \\
\text { Outside the Area }\end{array}$ & $\begin{array}{l}\text { Town/tourist attraction } \\
\text { Public recognition of town } \\
\text { Meeting new people } \\
\text { Industrial development }\end{array}$ & $\begin{array}{l}3.4 \\
2.5 \\
2.3 \\
3.0\end{array}$ & $\begin{array}{l}.31 \star \star \\
.21 \star \star \\
.24 \star \star \\
.38^{\star \star}\end{array}$ & $\begin{array}{c}2.8 \\
\text { "likely" }\end{array}$ \\
\hline $\begin{array}{l}\text { Economic Benefits } \\
\text { of Growth }\end{array}$ & $\begin{array}{l}\text { Increased land value } \\
\text { More jobs } \\
\text { Better paying jobs }{ }^{f} \\
\text { Better schools }\end{array}$ & $\begin{array}{l}2.6 \\
2.6 \\
2.7 \\
3.7\end{array}$ & $\begin{array}{l}-- \\
.34 \star \star \\
.46 * \star \\
--\end{array}$ & $\begin{array}{c}2.9 \\
\text { "1ikely" }\end{array}$ \\
\hline Other Effect ${ }^{g}$ & Cheap electricity ${ }^{f}$ & 4.6 & $.47 \star \star$ & \\
\hline
\end{tabular}

a Based on a principal components factor analysis of estimates of likelihood of effects (orthogonal factors, varimax rotation, no iterations).

$b_{1}=$ "certain to happen;" 7 = "almost impossible."

${ }^{C}$ Pearson $\underline{r}$ for effects in both surveys (5-point scale in January; 7-point scale in August).

dListed as "lower taxes" in January.

e ${ }_{\text {Not included in January. }}$

fFactor loadings less than .50 .

${ }^{9}$ Th1s effect was not in any of the five groups.

$\star \star p<.01$. 
"new people," and (5) economic benefits of growth, such as more and better-paying jobs. 71 The groups of effects appear in Table 5.1. Of the five types of effects, only those classified as "hazards" were seen as relatively unlikely; the remainder were seen as "likely."72

\subsubsection{Consistency of perceived likelihood from January to August}

As shown in Table 5.1 correlations of estimates of likelihood in January with those in August were all significant, but moderate. (We expected only moderate consistency because of the variability we introduced with the change from a 5-point scale to a 7-point scale for the ratings.) 73

\subsection{Perceived Desirability of Potential Effects of the Nuclear Plant}

To assess respondents' evaluations of the potential effects of the nuclear plant, we asked them to consider the 27 effects a second time, and to describe how desirable or undesirable each would be. Ratings were again made from seven choices: "extremely undesirable," "very undesirable," "undesirable," "neutral," "desirable," "very desirable," and "extremely desirable."74

\subsubsection{August ratings of desirability}

As shown in Table 5.2, effects rated least desirable were "increased crime" and "drugs in schools"; both were rated as "extremely undesirable." Twelve other outcomes were rated "undesirable" (3.5 or lower), including all of the seven disruptive effects of population growth, and all of the effects classified as hazards. Not surprisingly, the effects rated as most desirable were in the group called economic benefits of growth. "Better-paying jobs" and "more jobs" were both rated as "very desirable." Effects classed as increased business and new facilities, attention from outside the area, and economic benefits of growth all were rated as desirable. 
Table 5.2

Perceived Desirability of 27 Potential Effects of the Nuclear Plant

\begin{tabular}{|c|c|c|c|c|}
\hline Group of Effects ${ }^{a}$ & Effect & $\begin{array}{l}\text { Mean Rating gf } \\
\text { Desirability }\end{array}$ & $\begin{array}{c}\text { Percent Whose } \\
\text { Responses Agreed } \\
\text { in January and } \\
\text { August }\end{array}$ & Group Mean \\
\hline $\begin{array}{l}\text { Disruptive Effects } \\
\text { of Population } \\
\text { Growth }\end{array}$ & $\begin{array}{l}\text { Traffic congestion } \\
\text { More taverns and bars } \\
\text { Crowding in schools } \\
\text { Increased noise } \\
\text { Increased crime } \\
\text { Drugs in schools } \\
\text { Increased taxes } \\
\text { Housing shortages }\end{array}$ & $\begin{array}{l}2.6 \\
2.6 \\
2.1 \\
2.4 \\
1.9 \\
1.9 \\
2.3 \\
2.5\end{array}$ & $\begin{array}{l}78 \\
79 \\
89 \\
79 \\
94 \\
94 \\
87 \\
--\end{array}$ & $\begin{array}{c}2.2 \\
\text { "very } \\
\text { undesirable" }\end{array}$ \\
\hline $\begin{array}{l}\text { Hazards to Safety } \\
\text { and Environment }\end{array}$ & $\begin{array}{l}\text { Radiation hazard } \\
\text { Air pollution } \\
\text { Sabotage at plant } \\
\text { Foggy days } \\
\text { Pollution of lake }\end{array}$ & $\begin{array}{l}2.0 \\
2.3 \\
2.1 \\
2.6 \\
2.3\end{array}$ & $\begin{array}{l}89 \\
90 \\
90 \\
-- \\
88\end{array}$ & $\begin{array}{c}2.3 \\
\text { "very } \\
\text { undesirable" }\end{array}$ \\
\hline $\begin{array}{l}\text { Increased Business } \\
\text { and New Facilities }\end{array}$ & $\begin{array}{l}\text { More stores/shopping } \\
\text { More public entertainment } \\
\text { More recreation areas } \\
\text { More billboardsc } \\
\text { Increased business }\end{array}$ & $\begin{array}{l}5.5 \\
5.2 \\
5.5 \\
3.4 \\
5.6\end{array}$ & $\begin{array}{l}-- \\
96 \\
-- \\
-- \\
97\end{array}$ & $\begin{array}{c}5.0 \\
\text { "desirable" }\end{array}$ \\
\hline $\begin{array}{l}\text { Attention from } \\
\text { Outside the } \\
\text { Area }\end{array}$ & $\begin{array}{l}\text { Town/tourist attraction } \\
\text { Public recognition/town } \\
\text { Meet new people } \\
\text { Industrial development }\end{array}$ & $\begin{array}{l}4.4 \\
4.9 \\
5.2 \\
5.2\end{array}$ & $\begin{array}{l}77 \\
91 \\
98 \\
95\end{array}$ & $\begin{array}{c}4.9 \\
\text { "desirable" }\end{array}$ \\
\hline $\begin{array}{l}\text { Economic Benefits } \\
\text { of Growth }\end{array}$ & $\begin{array}{l}\text { Increased land value } \\
\text { More jobs } \\
\text { Better paying jobs } \\
\text { Better schools }\end{array}$ & $\begin{array}{l}5.0 \\
5.7 \\
6.0 \\
5.9\end{array}$ & $\begin{array}{l}-- \\
97 \\
97 \\
--\end{array}$ & $\begin{array}{c}5.7 \\
\text { "very } \\
\text { desirable" }\end{array}$ \\
\hline 0ther Effect & Cheap Electricity & 5.9 & 95 & \\
\hline
\end{tabular}

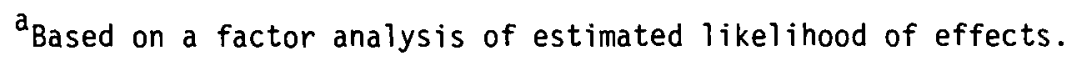

$b_{1}=$ "extremely undesirable" and 7 = "extremely desirable."

${ }^{c}$ Included only in August. 


\subsubsection{Consistency of ratings of desirability from January to August}

Table 5.2 shows the percentage of respondents whose responses agreed in January and August. "Agreement" means that the effect was rated "undesirable" in both surveys or was rated "desirable" or "neutral" in both surveys. ${ }^{75}$ Percentages ranged from $77 \%$ to $98 \%$ with an average of $90 \%$. Thus, most respondents were consistent in their identification of desir$a b l e$ and undesirable effects of the nuclear plant.

\subsection{Relationship of Likelihood of Effects and Desirability of Effects}

Table 5.3 summarizes the ratings by supporters and opponents of the likelihood and desirability of the groups of potential effects of the nuclear plant. The most undesirable effects, which were in the "hazards" group, were seen as least likely; the three groups of desirable effects associated with business expansion were all seen as relatively likely. There was one exception to the association of desirability and likelihood of effects - the undesirable effects of population growth were seen as quite likely.

\subsection{Support vs. Opposition to the Nuclear Plant and Anticipated Effects}

\subsubsection{Differences between supporters and npponents in estimatcs}

To investigate the relationship between attitudes toward the nuclear plant and expectations regarding its effects, we compared the estimates of $1 \mathrm{ikel}$ ihood made by supporters and opponents through use of t-tests. ${ }^{76}$ (Supporters were defined as neople who answered "yes" lu lhe "permit construction" question.) As shown in Table 5.4, supporters and opponents differed in rating almost all of the effects.

The differences were most pronounced in the groups of effects rated "undesirable." Compared with the supporters, the opponents estimated disruptive effects of population growth as more likely, especially crowding in the schools and increased crime. (These effects were generally seen as "likely," but opponents saw them as more likely.) Similarly, opponents estimated that hazards were more likely, especially radiation, air pollution, and pollution of Old Hickory Lake. 
Table 5.4

Support vs. Opposition to the Nuclear Plant and Perceived Likelihood of Its Effects

Effects $^{a} \quad \frac{\text { Mean Likelihood Rating }}{\substack{\text { Supporters } \\(N=196)}} \underset{\substack{\text { Opponents } \\(N=89)}}{\text { T-value }} \quad \frac{\text { Mean Likelihood for }}{\text { Supporters Opponents }}$

Disruptive Effects of Population Growth

$\begin{array}{llllc}\text { Traffic congestion } & 2.2 & 1.9 & 2.00^{* \star} & \\ \text { More taverns and bars } & 2.8 & 2.1 & 5.28^{\star \star} & \\ \text { Crowcing in schools } & 2.0 & 1.8 & 7.19 \star \star & 2.3 \\ \text { Increased noise } & 2.7 & 2.0 & 5.46^{\star \star} & 3.0 \\ \text { Increased crime } & 3.1 & 2.2 & 6.55^{* *} & \text { "likely" } \\ \text { Drugs in schools } & 3.0 & 2.1 & 5.99^{\star \star} & \\ \text { Increased taxes } & 3.3 & 2.5 & 5.85^{\star \star} & \\ \text { Shortages of housing } & 2.4 & 1.9 & 3.51^{\star \star} & \end{array}$

Hazards to Safety and Enyironment

\begin{tabular}{|c|c|c|c|c|c|}
\hline $\begin{array}{l}\text { Radiation hazard } \\
\text { Air pollution } \\
\text { Sabotage of plant } \\
\text { Foggy days } \\
\text { Pollution of lake }\end{array}$ & $\begin{array}{l}4.5 \\
3.8 \\
4.8 \\
4.3 \\
3.9\end{array}$ & $\begin{array}{l}3.1 \\
2.7 \\
3.8 \\
3.1 \\
2.6\end{array}$ & $\begin{array}{l}8.43^{\star \star} \\
8.24 \star \star \\
5.96 \star \star \\
6.53^{\star \star} \\
8.54 \star \star\end{array}$ & $\begin{array}{c}4.2 \\
\text { "perhaps" }\end{array}$ & $\begin{array}{c}3.1 \\
" l i k e l y "\end{array}$ \\
\hline
\end{tabular}

Increased Business and New Facilities

\begin{tabular}{|c|c|c|c|c|c|}
\hline $\begin{array}{l}\text { Mure slures/shoppiny } \\
\text { More publi.c entertainment }\end{array}$ & $\begin{array}{l}2.7 \\
2.9\end{array}$ & $\begin{array}{l}3.0 \\
3.7\end{array}$ & $\begin{array}{l}1.64 \\
4.44 * *\end{array}$ & & \\
\hline $\begin{array}{l}\text { More recreation areas } \\
\text { Mrre billboards } \\
\text { Inrreased business }\end{array}$ & $\begin{array}{l}2.9 \\
3.5 \\
2.4\end{array}$ & $\begin{array}{l}3.5 \\
3.1 \\
2.7\end{array}$ & $\begin{array}{l}3.39^{\star *} \\
2.37^{\star} \\
2.49^{* *}\end{array}$ & "likely" & "rikely" \\
\hline
\end{tabular}

Attention from Dutside tire Arca

Town/tourist attraction

Public recognition/town

Meet new people

Industrial development

$\begin{array}{lll}3.3 & 3.5 & 0.93 \\ 2.3 & 2.9 & 3.38 \star \star \\ 2.3 & 2.5 & 1.57 \\ 2.8 & 3.4 & 3.83 \star \star\end{array}$

2.7

"likely"

3.1

$3.83 * \star$

"likely"

Economic Benefits of Growth

\begin{tabular}{|c|c|c|c|c|c|}
\hline $\begin{array}{l}\text { Increased land value } \\
\text { More jobs } \\
\text { Better paying jobs } \\
\text { Better schools }\end{array}$ & $\begin{array}{l}2.4 \\
2.5 \\
2.4 \\
3.3\end{array}$ & $\begin{array}{l}2.8 \\
2.8 \\
3.3 \\
4.4\end{array}$ & $\begin{array}{l}2.22^{\star} \\
2.35^{\star} \\
5.73^{\star \star} \\
6.48^{\star \star}\end{array}$ & $\begin{array}{c}2.7 \\
\text { "likely" }\end{array}$ & $\begin{array}{c}3.3 \\
\text { "likely" }\end{array}$ \\
\hline \multicolumn{6}{|l|}{ er Effect } \\
\hline Cheap electricity & 5.2 & 4.3 & $4.98 * \star$ & & \\
\hline
\end{tabular}

\footnotetext{
${ }^{a}$ Grouped on the basis of a factor analysis.

$b_{1}=$ "certain to happen;" 7 = "almost impossible."

"People who answered "yes" to the "permit construction" question.

${ }^{\star} p<.05$.

$* * p<.01$.
} 


\subsubsection{Variation in favorability toward the plant as a function of anticipated effects}

To assess the relationship between estimated likelihood of effects and variation in favorability toward the nuclear plant, we performed a multiple regression analysis. ${ }^{77}$ The analysis yields an equation that indicates the combination of "predictors" that best accounts for variation in the "criterion" variable. As "predictor" variable, we used respondents' average estimate of likelihood for each of the five groups of effects (social disruption, hazards, increased business, outside attention, and economic benefit). Thus, we used five predictors. ${ }^{78}$ As our variable to be predicted (the "criterion"), we used a composite index of favorability toward the nuclear plant, which consisted of responses to the "permit construction" question and the "how far from your home" question. 79 The index ranged from favorable to unfavorable. The most favorable response was "definitely permit construction" within four miles of the respondent's home; the least favorable response was "definitely not permit construction" at the present site and not permit it within 100 miles.

Results appear in Table 5.5. Mean likelihood estimates for all five groups of effects were significantly correlated with favorability scores, but only three of the five groups of effects emerged as significant, independent predictors of favorability toward the nuclear plant. Respondents were relatively favorable if their estimates of the likelihood of economic gain were relatively high; respondents were relatively unfavorable to the extent that they believed likely the prospect of hazards or social disruption. The equation for predicting favorability from average estimates of likelihood was as follows:

$$
\begin{aligned}
& \text { Composite Index }=-.71 \text { (Hazards) }+.51 \text { (Economic Benefits) } \\
& -.61 \text { (Social Disruption) }+2.28 \text {. }
\end{aligned}
$$

The equation accounts for $51 \%$ of the variation in favorability toward the nuclear plant.

In conclusion, favorable attitudes toward the nuclear plant were associated with the belief that economic benefits were relatively likely and hazards were relatively unlikely. Although respondents generally believed social disruption likely, those with favorable attitudes believed 
Table 5.5

Estimates of thə Likelihood of Groups of Potential Effects of the Nuclear Plant as Predictirs of the Composite Iridex of Favorability towand It.

\begin{tabular}{|c|c|c|c|c|c|}
\hline Predictor Variab\|le & $\begin{array}{l}\text { Simpie } \\
\text { zorrelation }\end{array}$ & $\begin{array}{l}\text { Muitiple } \\
\text { Correlation }\end{array}$ & $\begin{array}{l}\text { Total \% of } \\
\text { Variance } \\
\text { Predicted }\end{array}$ & $\begin{array}{l}\text { Standardized } \\
\text { Regression } \\
\text { Coefficient }\end{array}$ & $F$-value \\
\hline $\begin{array}{l}\text { Hazards to Safetij } \\
\text { and Environment }\end{array}$ & $-.63 * \star$ & .63 & 39 & -.71 & $58.1 * *$ \\
\hline $\begin{array}{l}\text { Economic Benefit: of } \\
\text { Growth }\end{array}$ & $.4 c^{* \star *}$ & .68 & 47 & .51 & $17.0 * *$ \\
\hline $\begin{array}{l}\text { Disruptive Effects of } \\
\text { Population Growth }\end{array}$ & $-.50 \star \star$ & .71 & 51 & -.61 & $20.9 * * \star$ \\
\hline $\begin{array}{l}\text { Attention from 0 Jtside } \\
\text { the Area }\end{array}$ & $.20 * \star$ & .71 & 51 & .10 & 0.7 \\
\hline $\begin{array}{l}\text { Increased Business and } \\
\text { New Facilities }\end{array}$ & $.2^{-\star \star}$ & .71 & 51 & .10 & 0.6 \\
\hline
\end{tabular}

a Predictors entered ints the nultiple regression analysis were mean estimates of the likelihood of each cf five groups of potential effects. $N=261$. The F-value for regression was 52.9 ( $d f=5,255$; $p<.01$ ).

$b_{\text {Pearscn }} \underline{r}$ between predictir variable and composite index.

${ }^{\mathrm{C}}$ Multiple $r$ of composite with the predictor in the same row and all preciztcrs listed above it.

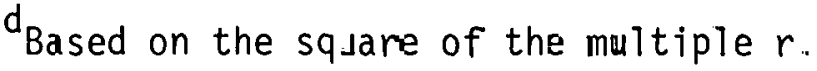

$e_{d \tilde{f}}=1,255$.

$\star \star p<.01$. 
it somewhat less likely. Favorability toward the nuclear plant was strongly related to beliefs about its potential effects.

6. DEMOGRAPHIC CHARACTERISTICS AND ATTITUDES TOWARD THE NUCLEAR PLANT

\subsection{Demographic Differences Between Supporters and Opponents}

To examine demographic differences between supporters and opponents of the nuclear plant, we compared the two groups. For characteristics based on membership in discrete categories, such as sex, we performed chisquared tests. ${ }^{80}$ Table 6.1 shows results associated with the following categorical variables: marital status, race, sex, employment status, occupation, and type of residence. The last four of these six characteristics showed significant differences.

A smaller proportion of women than men answered "yes" to the question of whether they would permit construction of the plant, although supporters were still a majority. Compared with people who were employed, a smaller proportion of unemployed persons were supporters of the plant. Most of those 1 isted as unemployed were women $(77 \%)$.

Support for the facility was relatively prevalent among people whose occupation was listed as manager or proprietor, clerical worker or salesperson, and blue collar worker. On the other hand, a majority of farmers and farm workers were opposed to construction of the nuclear plant (there were 18 farmers). People whose residence was on a farm also tended to oppose the plant more than did people in other types of residences (47\% of farm residents were opponents). Residents of farms represented more than one-fourth of the panel (77 people).

Although the statistical test indicated no difference in terms of race, the proportion of supporters among the 29 blacks - $83 \%$ - is considerbly larger than in the remainder of the panel. (The difference probably failed to reach statistical significance because of the small proportion of blacks in the panel.)

We compared supporters and opponents in terms of age, number of years of education, number of years in the county, and number of years at the same address through use of t-tests. As shown in Table 6.2, supporters were different from opponents on none of the four variables. 
Table 6.1

Demographic Characteristics of Supporters and Opponents:

Marital Status, Race, Sex, Employment Status, Occupa-

tion, and Type of Residence

\begin{tabular}{cccc}
$\begin{array}{c}\text { Demographic Variable } \\
\text { and Categories }\end{array}$ & $\begin{array}{l}\text { Number of } \\
\text { Persons in } \\
\text { Category } \\
(\mathrm{N}=285)\end{array}$ & $\begin{array}{c}\text { Percent of Persons in } \\
\text { Category who Would } \\
\text { Permit Construction }\end{array}$ & $\begin{array}{c}\text { Chi-squared } \\
\text { and df }\end{array}$ \\
\hline
\end{tabular}

Marital Status

Married

Single

Race

White

Black

Scx

Male

Female

136

149

201

81

Employed

Unemployed

Occupation $^{\mathrm{a}}$

Professional/technical

Farmer/Farm Laborer

Manager/proprietor

Clerical/sales/blue collarb

otherc
$225 \quad 69$

$60 \quad 68$

0.01

(df=1)
256

29

67

83

2.26

$(\mathrm{d} f=1)$

Type of Residence ${ }^{a}$

$\begin{array}{lrrr}\text { Farm } & 77 & 53 & 11.76^{*} \\ \text { Rural non-farm } & 22 & 68 & (\mathrm{df}=3) \\ \text { Hartsville, house } & 138 & 75 & \\ \text { Hartsville, other } & 12 & 83 & \end{array}$

${ }^{a}$ Some of the categories were collapsed.

bIncludes craftsmen, foremen, laborers, and service workers.

CIncludes housewives, students and "other" occupations.

${ }^{-*} \mathrm{p}<.05$.

${ }^{\star *} \mathrm{p}<.01$. 
Table 6.2

Demographic Characteristics of Supporters and Opponents: Age, Education, and Years of Residence

\begin{tabular}{lcccc}
\hline \multicolumn{1}{c}{$\begin{array}{c}\text { Demographic } \\
\text { Variable }\end{array}$} & $\begin{array}{c}\text { Mean Number of Years } \\
\text { Supporters }\end{array}$ & T-value & $\begin{array}{c}\text { Number of } \\
\text { Respondents }\end{array}$ \\
\hline Age in years & 47.3 & 44.8 & $1.34^{\mathrm{a}}$ & 285 \\
$\begin{array}{l}\text { Years of Education } \\
\text { (grades completed) }\end{array}$ & 11.2 & 11.4 & $0.67^{\mathrm{a}}$ & 282 \\
$\begin{array}{l}\text { Years of Residence } \\
\text { in Trousdale County }\end{array}$ & 32.4 & 30.5 & $0.85^{\mathrm{a}}$ & 282 \\
$\begin{array}{l}\text { Years at the same } \\
\text { Residence }\end{array}$ & 12.8 & 15.3 & $1.53^{\mathrm{a}}$ & 284 \\
\hline
\end{tabular}

${ }^{a}$ Not significant.

\subsection{Demographic Differences in Estimates of Likelihood of Effects of the Plant}

To understand why some demographic groups contained relatively more supporters or opponents, we examined their estimates of the likelihood of potential effects of the plant among selected groups. We obtained the average estimate of likelihood for each of the five groups of potential effects of the plant (social disruption, hazards, increased business, outside attention, and economic benefits) ${ }^{81}$ and used t-tests to compare the estimates by members of a demographic category with the estimates made by the remainder of the panel. Results appear in Table 6.3. Our general hypothesis held that groups containing relatively large proportions of supporters would tend to expect benefits as a consequence of the plant, and groups with relatively large proportions of opponents would tend to expect costs.

As a group, blacks tended toward support of the plant, but they did not see it as simply beneficial. They thought hazards relatively likely and they thought increased business and outside attention relatively likely. Our interpretation is that blacks saw the "trade" as an extreme one: both risks and benefits seemed relatively likely. 
Table 6.3

Estimates of the Likel thood of Effects of the Proposed Nuclear Plant as a Function of Demographic Characteristics

\begin{tabular}{|c|c|c|c|c|c|c|}
\hline \multirow[b]{2}{*}{$\begin{array}{l}\text { Demographic } \\
\text { Cateogry }\end{array}$} & \multirow{2}{*}{$\begin{array}{l}\text { Number of } \\
\text { Respondents } \\
\text { in Ca } \overline{\text { ingory }}\end{array}$} & \multicolumn{5}{|c|}{ Mean Estimate of Likelihood for Groups of Potential Effects } \\
\hline & & $\begin{array}{l}\text { Social } \\
\text { Disrustion }\end{array}$ & Hazards & $\begin{array}{l}\text { Increased } \\
\text { Business }\end{array}$ & $\begin{array}{l}\text { Outside } \\
\text { Attention }\end{array}$ & $\begin{array}{l}\text { Economic } \\
\text { Benefits }\end{array}$ \\
\hline \multicolumn{7}{|c|}{ Groups Containing Relatively Large Proportians of Supporters } \\
\hline Blacks & 29 & 2.7 & $3.4 *$ & $2.7 *$ & $2.4 * \star$ & 2.6 \\
\hline Males & 136 & 2.6 & $4.0 *$ & $2.9 *$ & 2.8 & $2.8 *$ \\
\hline $\begin{array}{l}\text { Managers and } \\
\text { Proprietors }\end{array}$ & 25 & 2.7 & 4.2 & 3.0 & 2.9 & 2.9 \\
\hline $\begin{array}{l}\text { Salespersons, Cleri } \\
\text { Workers, and Blue } \\
\text { Coliar Workers }\end{array}$ & 130 & 2.6 & 4.0 & 2.9 & 2.8 & $2.7 *$ \\
\hline \multicolumn{7}{|c|}{ Groups Containing Relatively Large Proportions of Opponents } \\
\hline Females & $14 \varepsilon$ & 2.5 & $3.7 *$ & $3.7 *$ & $2.8 *$ & 3.0 \\
\hline $\begin{array}{l}\text { Farmers and Farm } \\
\text { Workers }\end{array}$ & 12 & $2 . L$ & 3.6 & 3.2 & 2.9 & $3.3 \star \star$ \\
\hline Residents of Farms & 77 & $2.3 * \star$ & $3.7^{*}$ & 2.9 & 2.7 & 3.0 \\
\hline
\end{tabular}

"Mean values on a scale of 1 to $T$, where $l . C 1=$ "certain to happen" and $7.0=$ "almost impossible" (among people who answered the "permit corstruction" question). ${ }^{b}$ Females included $38 \%$ opponents; farmers aró farm workers included $56 \%$ opponents; residents of farms
included $47 \%$ opponents.

*Significantly different from the remainder of respondents at $p<. .05$.

$\star *$ Significantly different from the remainder of respondents at $p<.01$. 
The sex difference in support vs. oppositon was associated with differences in three groups of effects. Compared with males; females thought more likely the prospect of hazards and less likely the prospect of increased business and outside attention. As a group, females not only tended more toward opposition than did males, but saw the "trade" as more unfavorable than did males. This result agrees with our general hypothesis.

The occupational groups that tended most toward support were: (a) managers and proprietors, (b) clerical workers, salespersons, and blue collar workers. Managers and proprietors' estimates of likelihood were not different from those of the rest of the panel. Among the clerical/sales/blue collar group, economic benefits were rated more likely than in the rest of the panel. Thus, the clerical/sales/blue collar group saw the "trade" as relatively favorable.

Among farmers, the group most opposed to the nuclear plant, only one difference appeared: they thought relatively unlikely the prospect of economic benefits, including increases in land values and better pay. Farmers thus saw the "trade" as relatively unlikely to bring economic gain.

Residents of farms, who included only $53 \%$ supporters, thought relatively likely the prospect of both social disruption and hazards. The group emphasized what would be salient disadvantages for people in rural homes such things as crowding and pollution.

In summary, results generally supported our hypothesis that demographic groups leaning toward support or opposition to the plant would also see the trade as bringing corresponding benefits or costs. The hypothesis failed to hold for (a) managers or proprietors, who saw the "trade" as did the rest of the panel; and (b) blacks, who saw the "trade" in relatively extreme terms.

\section{ATTITUDES TOWARD THE NUCLEAR PLANT AND INFORMATION ABOUT IT}

\subsection{Respondents' Knowledge and Information about the Nuclear Plant}

\subsubsection{Factual knowledge}

In August we asked respondents seven multiple-choice questions about the nuclear facility, concerning the number of reactors, the number of years required for construction, and number of acres required, TVA's estimate of 
the cost, the maximum number of construction workers required on site, the size of the operating staff, and the number of years the facility is expected to operate. 82

Table 7.1 shows the percentage of respondents who answered each question correctly. We scored as "correct" what we considered reasonable approximations of the information available to the public at the time through newspapers, television, and TVA. Only three of the seven questions were answered correctly by more than half of the respondents - nearly $60 \%$ of them knew that the site would occupy between 1,000 and 2,000 acres of land. About half knew the number of reactors, the size of the operating staff, the maximum number of construction workers, and the number of years required for construction. Only about one in four knew that the plant was expected to operate for less than 50 years.

There was considerable variability in the number of questions each respondent answered correctly. The average respondent knew three or four correct answers (the average was 3.6). Over half of the panel (58\%) answered three or more questions correctly. A total of 44 people, or about $15 \%$, answered six or seven of the questions correctly. The number of questions answered correctly was moderately correlated with the number of years of education $(r=.34, N=284, p<.01)$.

\subsubsection{Sources of information}

Respondents wcre asked where they obtained information about the proposed nuclear facility. Each respondent could list up to four sources. The average respondent mentioned 2.4 sources. Table 7.2 shows the percent. nf respondents who mentioned each of several sources. The sources most commonly mentioned were television and newspapers, each of which provided information to nearly half of the panel.

\subsection{Support vs. Opposition to the Nuclear Plant as a Function of Information About it}

A comparison of supporters and opponents in terms of the average number of sources of information they mentioned yielded no differences. Table 7.2 shows the percent of supporters and opponents who mentioned each of several sources. Using chi-squared tests, we found only one statistically significant difference; a much greater percentage of supporters than opponents mentioned 
Table 7.1

Factual Knowledge About the Nuclear Plant

\begin{tabular}{|c|c|c|c|}
\hline Topic of Factual question & $\begin{array}{r}\text { Correct } \\
\text { Response }\end{array}$ & $\begin{array}{l}\text { Responses Counted } \\
\text { as Correct }\end{array}$ & $\begin{array}{l}\text { Percent of Responses } \\
\text { Scored as Correct } \\
(N=288)\end{array}$ \\
\hline Acreage required & 2,000 acres & $1,000-2,500$ acres & $57 \%$ \\
\hline Number of reactors & four $(4)$ & four (4) & $50 \%$ \\
\hline Operating staff & about 350 persons & 200-500 persons & $48 \%$ \\
\hline $\begin{array}{l}\text { Peak number of construction } \\
\text { workers }\end{array}$ & about 5,300 persons & $4,000-7,000$ persons & $45 \%$ \\
\hline Years to build the plant & eight years ${ }^{b}$ & $7-10$ years & $51 \%$ \\
\hline Cost to build & $\$ 2.5$ billion ${ }^{\mathrm{a}}$ & $\$ 1.5-3.5$ billion & $30 \%$ \\
\hline Years of operation & about 35 years & Fewer than 50 years & $26 \%$ \\
\hline
\end{tabular}

$\mathrm{a}_{\text {At }}$ the time of the survey, the publfclzed cost was $\$ 2.15$ to 2.5 billion, but a more recent estimate is $\$ 3.5$ billion.

'TVA's estimate. 
TVA as a source of information. This finding agrees with our hypothesis that respondents would tend to use sources consistent with their own position. Besides TVA, the only other source that clearly favored construction of the plant was the local radio station, WJKM. The difference between the percentages of supporters and opponents mentioning WJKM as a source was not significant, though it tended in the predicted direction. We identified no sources as clearly opposed to the nuclear plant, and could not test the hypothesis that opponents would tend to use sources consistent with their views.

Table 7.2

Supporters'. and Opponents' Sources of Information about the Proposed Plant

Percent of Respondents Mentioning Source

\begin{tabular}{|c|c|c|c|c|}
\hline \multirow[b]{2}{*}{ Source of Information ${ }^{a}$} & & & & \multirow[b]{2}{*}{$\begin{array}{c}\text { Chi-squared } \\
(d f=1)\end{array}$} \\
\hline & $\begin{array}{l}\text { Supporters } \\
(N=196)\end{array}$ & $\begin{array}{l}\text { Opponents } \\
(\mathrm{N}=89)\end{array}$ & $\begin{array}{l}\text { Whole Panel } \\
\qquad(\mathrm{N}=285)\end{array}$ & \\
\hline Local Newspapers & 41 & 52 & 44 & 2.51 \\
\hline Other Newspapers & 35 & 40 & 37 & .64 \\
\hline $\begin{array}{l}\text { Magazines and other } \\
\text { printed news media }\end{array}$ & 16 & 17 & 17 & n \\
\hline Television & 37 & 47 & 40 & 2.37 \\
\hline Local radio (WJKM) & 14 & 9 & 12 & .90 \\
\hline Other radio stations & 15 & 9 & 13 & 1.35 \\
\hline $\begin{array}{l}\text { Friends, acquaintances, } \\
\text { co-worker's }\end{array}$ & 16 & 21 & 18 & .94 \\
\hline TVA office & 29 & 5 & 21 & $19.92 \times \cdots$ \\
\hline Library & 10 & 11 & 10 & .04 \\
\hline Meetings of Organizations & 4 & 5 & 4 &.$n ?$ \\
\hline
\end{tabular}

${ }^{a}$ Each respondent could list up to four sources. The average respondent mentioned 2.4 sources.

${ }^{b}$ Test for relationship between two dichotomous variables: support vs. oppose the plant and mention vs. not mention the source.

$\star \star p<.01$. 


\section{INDICATORS OF THE PERCEIVED QUALITY OF LIFE IN HARTSVILLE}

\subsection{Changes in Indicators of the Perceived Quality of Life}

Results of the January survey 83 indicated that respondents evaluated their community very favorably. They gave many reasons for liking i ife in Hartsville and had few complaints. In August we again asked about satisfaction with services, characteristics of neighborhoods, and the general quality of life.

\subsubsection{Satisfaction with services}

On both surveys respondents rated their satisfaction with 11 services available in the community on a scale from 1.0 to 5.0 ("very satisfied" to "very dissatisfied"). Table 8.1 shows mean ratings in January and August. of the eleven services, seven received ratings of "satisfied" in August, indicated by mean ratings between 1.0 and 2.5. In other words, respondents indicated that they were satisfied with most services. They were slightly less than satisfied with sewage, zoning, and medical care; they were dissatisfied with the availability of housing.

To assess the consistency of ratings from January to August, we calculated correlation coefficients. As shown in Table 8.1, all were significant; they indicate a reasonably high degree of consistency of ratings in August with those in January. To examine differences in the average response, we conducted t-tests. As shown in Table 8.1, there were virtually no changes in the average response from January to August in satisfaction with 10 of the 11 services. One small difference appeared. In August, respondents were somewhat more satisfied with the availability of housing than they had been in January, and the small change was fairly consistent. Between January and August some land developers made plans to construct mobile-home parks, which could explain why a few respondents thought housing was more available in August.

\subsubsection{Ratings of characteristics of neighborhoods}

In both January and August we asked respondents to rate their neighborhoods on attributes such as "noisy vs. quiet." Respondents were shown 10 pairs of adjectives and asked to make a rating for each pair on a 7-point scale. 84 
Table 8.1

Satisfaction with Local Services

\begin{tabular}{|c|c|c|c|c|c|}
\hline Tuma of colion & $\begin{array}{l}\text { Mean Rat } \\
\text { Satisfac }\end{array}$ & $\begin{array}{l}\text { ing of } \\
\text { tiona }\end{array}$ & $\begin{array}{l}\text { Correlation } \\
\text { of January }\end{array}$ & $\begin{array}{c}\text { T-test } \\
\text { of }\end{array}$ & Number of \\
\hline Public schools & 2.4 & 2.4 & $.57 * \star$ & 0.88 & 275 \\
\hline Streets and highwavs & 2.0 & 2.7 & $.38 * \star$ & 0.44 & 286 \\
\hline Police protection & 2.5 & 2.4 & $.42^{\star \star}$ & 0.69 & 280 \\
\hline Fire protection & 2.2 & 2.2 & $.45 \star \star$ & 0.14 & 275 \\
\hline Telephone service & 2.1 & 2.1 & $.53 \star \star$ & 0.15 & 284 \\
\hline Sewage treatment & 2.6 & 2.6 & $.47 * \star$ & 0.13 & 227 \\
\hline Water supjly & 2.3 & 2.2 & $.37 \star \star$ & 1.76 & 265 \\
\hline Zoning laws & 2.8 & 2.8 & $.35 * \star$ & 0.88 & 230 \\
\hline Garbage pickup & 2.4 & 2.4 & $.29 * \star$ & 0.17 & 239 \\
\hline Housing availability & 3.4 & 3.3 & $.46 \star \star$ & $2.87 \star \star$ & 280 \\
\hline Medical care & 2.6 & 2.5 & $.41 * \star$ & 1.44 & 279 \\
\hline
\end{tabular}

"Very satisfied" $=1.0$, "Satisfied" $=2.1$, "Not sure" $=3.0$, "Dissatisfied" $=4.0$, "Very dissatisfied" $=5.0$.

$* * p<.01$. 
Table 8.2 presents the average responses in January and August. In August, respondents as a group described their neighborhoods as "private," "stable," "uncrowded," "pleasant," "quiet," "safe," and "pretty." Respondents saw their neighbors as "similar" to themselves, but not particularly "close knit" or "wealthy." For adjectives given in both surveys, responses were fairly consistent with those given in January, as indicated by the correlation coefficients.

To assess differences in the average ratings from January to August, we performed t-tests. As shown in Table 8.2, very slight changes occurred in four of the seven attributes assessed in both surveys. Compared with January, respondents in August evaluated their neighborhoods as somewhat more noisy, crowded, unpleasant, and changing. These differences could reflect respondents' anticipation of an influx of workers or even actual changes in the neighborhoods, although construction of the power plant had not even been approved in August. 85 To assess the extent of local development, we obtained records of building permits. In 1974, the city of Hartsville granted 12 building permits. In 1975, there were nearly twice as many permits (23). In 1976, 20 permits had been granted as of May 26, reflecting nearly twice the rate of planned construction projects as in the previous year. For the county, records of building permits began in 1976 . There were eight permits during the first five months of 1976. Of the new development we actually observed, most was apparently designed to accommodate new people. Projects completed between January and August 1975 included two branch banks (Citizens' Bank and the Bank of Hartsville), two small grocery stores, one mobile home sales lot, and a 12-unit addition to the local motel. It is possible, of course, that this construction was planned before the builders learned of the plans to build the nuclear plant. We have no direct evidence of changes in neighborhoods, but some neighborhoods could have become more noisy and crowded. The largest change in ratings from January to August involved a shift of an entire scale-point (on a 7-point scale) on the question of "changing vs. stable." Respondents said their neighborhoods were less "stable" and more "changing" in August. 
Table 8.2

Ratings of C.aracteristics of Neighborhoods

\begin{tabular}{|c|c|c|c|c|c|}
\hline Characteristic ${ }^{\mathrm{a}}$ & $\frac{\text { Mean }}{\text { January }}$ & $\frac{\text { Rating }}{\text { August }}$ & $\begin{array}{l}\text { Correlation } \\
\text { of January } \\
\text { with August }\end{array}$ & $\begin{array}{l}\text { T-test of } \\
\text { Differences }\end{array}$ & $\begin{array}{l}\text { Number of } \\
\text { Respondents }\end{array}$ \\
\hline Private vs. not private & $=-$ & 2.7 & -- & -- & 288 \\
\hline Changing vs. stable & 6.0 & 5.0 & $.20 * \star$ & $6.94 * \star$ & 286 \\
\hline $\begin{array}{l}\text { People similar to re vs. people } \\
\text { dissimilar to me }\end{array}$ & 2.3 & 2.5 & $.34 * *$ & 1.32 & 283 \\
\hline Crowded vs. uncrowded & E.9 & 5.5 & $.36 * \star$ & $2.70 \star \star$ & 282 \\
\hline Close-knit vs. not close-rnit & 3.5 & 3.6 & $.31 * \star$ & 0.14 & 278 \\
\hline Unsafe vs. safe $e^{b}$ & -- & 5.8 & -- & -- & 288 \\
\hline Unpleasant vs. pleasant & 6.5 & 6.1 & $.23 * *$ & $4.63 * \star$ & 284 \\
\hline Wealthy vs. poor ${ }^{b}$ & -- & 4.0 & -- & -- & 286 \\
\hline Noisy vs. quiet & 5.7 & 5.3 & $.46^{\star \star}$ & $3.72 \star \star$ & 287 \\
\hline Pretty vs. uglyc & 2.5 & 2.5 & $.35 * \star$ & 0.73 & 286 \\
\hline
\end{tabular}

${ }^{a}$ For each adjective pair, responses were made on a 7-step scale. We scored the adjective given first as 1.0 and the adjective given second as 7.0 .

${ }^{b}$ Asked in August only.

CAsked in January as "attractive vs. unattractive."

$\star \star p<.011$. 


\subsubsection{General evaluations of the quality of life}

To assess general evaluations of the quality of life, we asked respondents how satisfied they were with their own lives and with life in Hartsville.

General satisfaction. In both January and August, respondents were shown a picture of a ladder with 11 steps (numbered 0 through 10). They were asked to indicate where on the ladder they stood, if the top (10) represented the "best possible life" for them and the bottom represented "the worst possible life." The question was asked in reference to three points in time: five years ago, the present, and five years hence. Results appear in Table 8.3. In August, respondents indicated moderate satisfaction, somewhat higher than they remembered five years ago, and not quite as high as they expected in five more years. Such responses are typical of other research using this series of questions. ${ }^{86}$ Ratings during January showed reasonable consistency with ratings in August (shown in Table 8.3 ). Tests of differences between average ratings in january and August revealed that in August, respondents reported somewhat less satisfaction in both the past and present than they had reported in January. This slight decline in evaluations of the quality of life could be due to many factors, including apprehensions regarding construction of the nuclear facility. Because the decline occurred during a period of nationwide economic recession, however, we are reluctant to interpret it as an effect of the plans to construct the nuclear plant.

Life in Hartsville. Respondents also rated "life in Hartsville" on a 5-point scale, with 1.0 indicating "excellent" and 5.0 indicating "poor." As shown in Table 8.3, respondents indicated no change in their evaluation of Hartsville--it was rated "good" in both surveys. Even though respondents reported a very slight decline in the quality of their own lives, they did not think less of "life in Hartsville." This apparent inconsistency may reflect respondents' attachment to Hartsville and their liking for the town. Perhaps respondents' personal satisfaction would have to decline greatly before their perception of Hartsville would change.

In brief, there was a very slight decline in the generally high ratings of neighborhoods and in the generally high ratings of the quality of life. 
Table 8.3

General Evaluations of the Quality of Life in Hartsville

\begin{tabular}{|c|c|c|c|c|c|}
\hline Type of Satisfaction & $\frac{\text { Mean } F}{\text { January }}$ & $\frac{\text { Rating }}{\text { August }}$ & $\begin{array}{l}\text { Correlation } \\
\text { of Ratings }\end{array}$ & $\begin{array}{l}\text { T-test of } \\
\text { Differences }\end{array}$ & $\begin{array}{l}\text { Number of } \\
\text { Respondents }\end{array}$ \\
\hline $\begin{array}{l}\text { Satisfaction with life } \\
\text { five-years ago }\end{array}$ & 5.7 & 5.1 & $.57 \star \star$ & $4.10 \star \star$ & 274 \\
\hline $\begin{array}{l}\text { Satisfaction with life } \\
\text { at presenta }\end{array}$ & 6.6 & 6.4 & $.55^{\star \star}$ & $2.09 *$ & 280 \\
\hline $\begin{array}{l}\text { Satisfaction with : ife } \\
\text { five-years hencea. }\end{array}$ & 7.3 & 7.3 & $.36 * *$ & 0.12 & 269 \\
\hline $\begin{array}{l}\text { Satisfaction with } \\
\text { life in Hartsvilleb }\end{array}$ & 2.0 & 2.1 & $.58^{\star \star}$ & 1.22 & 286 \\
\hline
\end{tabular}

${ }^{a} 0=$ "worst possible;" $10=$ ' jest possible."

$b_{1}=$ "excellent;" 5 = "pocr."

$*_{p}<.05$.

$\star * p<.101$. 
The most marked change involved a tendency to see neighborhoods as more changing in August than in January. Ratings of "life in Hartsville" did not appreciably change. Because the decline in ratings was so slight, and because of the concurrent period of national economic recession, we are reluctant to interpret the data as evidence that the plans to build a nuclear plant had any adverse effect on the perceived quality of life.

\subsection{Attitudes Toward the Nuclear Plant and the Perceived Quality of Life}

Our general hypothesis was that opponents of the power plant, compared with supporters, would show a greater decline in perceptions of the quality of life from January to August. To test this hypothes is we examined ratings of services, neighborhoods, and the quality of life in general.

\subsubsection{Support vs. opposition and ratings of services}

As shown in Table 8.4, compared with supporters, opponents were slightly more satisfied with the current availability of housing and somewhat less satisfied with the schools. (As reported in Section 5, opponents also gave higher estimates of the likelihood of housing shortage and crowded schools than did supporters.)

\subsubsection{Support vs. opposition and perceived characteristics of neighborhoods}

There were two very slight but statistically significant differences in ratings of neighborhoods. Opponents thought their neighborhoods were prettier and more private than did supporters.

\subsubsection{Support vs. opposition and general evaluations of the quality of life}

As shown in Table 8.4, supporters and opponents differed little in August in their evaluations of the quality of life. Opponents indicated they had been happier five years ago than supporters, but there was no difference in ratings of present and future. One interpretation is that the supporters saw more improvement over the past five years, a sign of optimism among supporters, but their ratings of the future were not significantly higher. Also shown in Table 8.4, there were no differences between supporters and opponents in the amount of change in ratings from January to August. In 
Table 8.4

Support vs. Opposition to the Proposed Plant as a Function of Perceived Quality of Life

\begin{tabular}{|c|c|c|c|c|}
\hline \multirow[b]{2}{*}{ Aspect of Perceived Quality of Life } & \multicolumn{2}{|c|}{ Mean Rating } & \multirow[b]{2}{*}{ T-value } & \multirow{2}{*}{$\begin{array}{l}\text { Number of } \\
\text { Respondents }\end{array}$} \\
\hline & Supporters & Opponents & & \\
\hline \multicolumn{5}{|l|}{ Satisfaction with Services } \\
\hline $\begin{array}{l}\text { Public schools } \\
\text { Streets } \\
\text { Police } \\
\text { Fire protection } \\
\text { Telephone } \\
\text { Sewage } \\
\text { Water } \\
\text { Zoning } \\
\text { Garbage pickup } \\
\text { Housing availability } \\
\text { Medical care }\end{array}$ & $\begin{array}{l}2.3 \\
2.1 \\
2.4 \\
2.2 \\
2.1 \\
2.5 \\
2.2 \\
2.7 \\
2.4 \\
3.4 \\
2.5\end{array}$ & $\begin{array}{l}2.6 \\
2.0 \\
2.4 \\
2.3 \\
2.1 \\
2.7 \\
2.1 \\
2.9 \\
2.6 \\
3.0 \\
2.5\end{array}$ & $\begin{array}{l}2.14^{\star} \\
0.19 \\
0.52 \\
0.75 \\
0.24 \\
1.14 \\
0.68 \\
1.33 \\
1.38 \\
2.63^{\star \star} \\
0.35\end{array}$ & $\begin{array}{l}280 \\
283 \\
285 \\
283 \\
282 \\
264 \\
281 \\
282 \\
270 \\
283 \\
283\end{array}$ \\
\hline \multicolumn{5}{|l|}{ Characteristics of Neighborhoods $^{b}$} \\
\hline $\begin{array}{l}\text { Private - not private } \\
\text { Changing - stable } \\
\text { People similar - dissimilar } \\
\text { Crowded - uncrowded } \\
\text { Close-knit - not close-knit } \\
\text { Pleasant - unpleasant } \\
\text { Noisy - quiet. } \\
\text { Pretty - ugly } \\
\text { Safe - unsafe } \\
\text { Wealthy - poor }\end{array}$ & $\begin{array}{l}2.9 \\
5.0 \\
2.4 \\
5.6 \\
3.5 \\
6.0 \\
5.3 \\
2.7 \\
5.9 \\
4.1\end{array}$ & $\begin{array}{l}2.4 \\
5.0 \\
2.6 \\
5.4 \\
3.6 \\
6.1 \\
5.2 \\
2.3 \\
5.7 \\
3.9\end{array}$ & $\begin{array}{l}1.97 \star \\
0.01 \\
1.02 \\
0.93 \\
0.01 \\
0.22 \\
0.31 \\
2.05 \star \\
0.98 \\
1.41\end{array}$ & $\begin{array}{l}285 \\
284 \\
283 \\
281 \\
283 \\
283 \\
285 \\
285 \\
285 \\
283\end{array}$ \\
\hline \multicolumn{5}{|l|}{ Quallty of Life (Aügust) } \\
\hline $\begin{array}{l}\text { Five-years ago } c \\
\text { Present } c \\
\text { In five years } c \\
\text { Satisfaction/life in Hartsville } e^{a}\end{array}$ & $\begin{array}{l}5.0 \\
6.2 \\
7.4 \\
2.1\end{array}$ & $\begin{array}{l}5.6 \\
6.6 \\
7.1 \\
2.1\end{array}$ & $\begin{array}{l}2.03^{\star} \\
1.16 \\
1.19 \\
0.55\end{array}$ & $\begin{array}{l}280 \\
281 \\
277 \\
285\end{array}$ \\
\hline \multicolumn{5}{|c|}{ Change in Quality of Life Since January } \\
\hline $\begin{array}{l}\text { Rating of five-years ago } \\
\text { Rating present } \\
\text { Rating of tive-years hence }\end{array}$ & $\begin{array}{l}-0.6 \\
-0.2 \\
-0.1\end{array}$ & $\begin{array}{r}-0.4 \\
-0.2 \\
0.3\end{array}$ & $\begin{array}{l}0.64 \\
0.12 \\
1.20\end{array}$ & $\begin{array}{l}271 \\
277 \\
267\end{array}$ \\
\hline \multicolumn{5}{|c|}{$\begin{array}{l}a_{1.0}=\text { "very satisfied;" } 5.0=\text { "very discatisfied." } \\
{ }^{b} \text { First adjective }=1.0 \text {; and } 2 \text { nd adjective }=7.0 . \\
{ }^{c} \text { Lowest rating }=0.0 \text {; highest rating }=10.0 \text {. } \\
{ }^{d} \text { Difference between rating in January and August; positive valucs mean higher ralings in August. } \\
\star p<.05 \text { (by chance alone, one or two of the t-tests in this table would be expected to be significant }\end{array}$} \\
\hline
\end{tabular}


conclusion, the evidence generally failed to support our hypothesis that opponents of the nuclear plant would experience a greater decline in the quality of life than would supporters.

\section{INTERPRETATION AND DISCUSSION OF THE RESULTS OF THE AUGUST SURVEY}

\subsection{Subjective Reactions to the Nuclear Plant}

The purpose of the August survey was to examine residents' attitudes toward the nuclear plant and their perceptions about the quality of life before construction. This section summarizes and discusses findings related to attitudes and perceived quality of life and their implications for other types of behavior.

\subsubsection{The proportions of support and opposition to the nuclear plant}

Attitudes toward the nuclear plant were predominantly favorable; $69 \%$ of respondents said that if they could decide, they would allow it to be built. They were labelled "supporters." The remaining 31\% were "opponents." Our use of a "forced choice" question probably exaggerated somewhat the proportions of both supporters and opponents, although only three of the 288 respondents declined to answer the question. Our findings were roughly similar to those of the January survey, 87 in which $65 \%$ of the 332 people who answered were supporters, $25 \%$ were opponents, and 10\% were undecided (18 people delined to answer).

Wilh about two-thirds of the panel in favor of the facility, the respondents in the August survey seem typical of other populations surveyed in the United States. A recent report by Roger Kasperson and associates stated:

... surveys conducted in the United States are remarkably consistent in their conclusion that a large majority of Americans favor the development of nuclear power. Approval ranges from 47 to 69 percent. (The pro-nuclear vote in the California referendum was $67 \%)$. (p. 27).88 
Results of the January and August surveys may also be compared with a telephone survey of opinions about the Hartsville nuclear plant conducted by The University of Tennessee College of Communications in March 1975 among residents of five counties surrounding Hartsville. ${ }^{89}$ Results for Trousdale County showed $65 \%$ in favor of the facility, $22 \%$ opposed, and 13\% undecided. The findings are based on 145 responses from a sample of 156 Trousdale County families with telephones. Despite differences in procedures of interviewing, the results of the telephone survey indicate proportions of support and opposition very similar to those of the January survey, and roughly comparable with those of the August survey. All three surveys suggest that a substantial proportion of the residents of the county favor construction of the nuclear plant.

\subsubsection{Consistency of attitudes toward the nuclear plant}

Results of the August survey showed that respondents' views were highly consistent from January to August 1975. Despite the intervening six months and despite differences in our interviewing procedures, $76 \%$ of the panel were consistently classified as supporters or opponents; only $10 \%$ changed their opinions from support to opposition or vice versa. These data suggest that attit:ydes toward the nuclear plant were very stable, even during a period marked by public controversy about the nuclear plant.

\subsubsection{Attitudes toward TVA's performance}

TVA received generally high ratings, as in the January survey 90 and in the telephone survey of March 1975.91 As might be expected, supporters of the plant gave TVA higher ratings than did opponents. However, with $94 \%$ of supporters and $74 \%$ of opponents giving TVA "average" or higher ratings, we could not conclude that people sought consistency between their attitudes toward the nuclear plant and TVA.

\subsubsection{Attitudes toward a coal-fired plant instead of a ruclear plant}

Nearly half of the respondents (48\%) favored a coal-fired plant, with $30 \%$ opposed and $22 \%$ undecided. These findings may be compared with the 
results of the telephone survey of March 1975 which showed $63 \%$ of the sample from the "five-county impact area" in favor of a coal plant, 74\% in favor of a steel plant, and $52 \%$ in favor of a chemical plant. Although the August survey showed fewer proponents of a coal plant than did the telephone survey, both surveys suggest that a majority or near majority of residents would also accept other large-scale industrial developments.

Our findings suggested that the proponents of a coal-fired facility are not necessarily the same people as proponents of the nuclear plant. Most supporters of the nuclear plant would support a coal-fired plant (38\% of respondents would support both); most opponents of the nuclear plant would oppose a coal-fired plant (15\% of the panel). Many were undecided about the coal-fired plant (22\%). However, $25 \%$ of respondents would support one type of plant but oppose the other. For these $25 \%$, we inferred that the differences between nuclear and coal-fired plants were a critical component of support or opposition to the nuclear plant. One implication is that for most residents, attitudes may not hinge on the type of industry or its characteristics, but on features that such developments have in common such as the production of jobs. However, for a sizeable fraction of residents, the specific characteristics of the development may be critical to attitudes toward it:

\subsubsection{Support vs. opposition and expectations about the effects of the nuclear plant}

As in January, support or opposition to the nuclear plant was strongly related to estimates of the likelihood of potential effects of the plant. Compared with opponents, supporters gave relatively high estimates of the likelihood of such economic effects as more jobs, better pay, industrial growth, increased business, more tourism, and new facilities. Both supporters and opponents believed that hazards such as pollution and radiation were relatively unlikely, but opponents thought them more likely. Supporters and opponents both anticipated disruptive effects of growth, such as crowded schools and streets, but supporters believed such effects less likely. Supporters were apparently willing to "trade" the undesirable effects of crowding and development for the desirable efferts 
of economic growth. Opponents of the nuclear plant had different expectations about its consequences and saw the trade in different terms. Compared with supporters, they evaluated the risks as more likely and the benefits as less likely. The findings indicate that for supporters and opponents alike, the nuclear plant represents a trade, but supporters see the trade as more favorable than do opponents. Issues related to such a trade may be common when any large-scale development is undertaken. 92

These findings suggest that beliefs about the effects of the nuclear plant could influence a person's favorability toward it. Of course, favorability could also influence beliefs about the effects of the plant. However, if beliefs do affect support or opposition to the plant, a change in expectations could change a person's support or opposition to the facility.

Another implication concerns the cognitive nature of attitudes toward a nuclear plant, or toward nuclear power in general. The recent report by Roger Kasperson and colleagues questions the extent to which attitudes are cognitive, citing analyses that link such attitudes to fears and anxieties about nuclear war. ${ }^{93}$ The results of the August survey show that over $50 \%$ of the statistical variation in attitudes can be predicted from purely cognitive statements about the likelihood of effects of the nuclear plant. Our procedures were based on a standard list of effects, not lists of effects tailored to each individual.94 Thus, our analysis could conceivably underestimate the strength of the substantial cognitive component of attitudes toward the nuclear plant. However, even considering the technical problems of measuring attitudes and heliefs, there remains con. siderable unaccounted variation in attitudes that could reflect a purely "emotional" component.

\subsubsection{Demographic differences in support vs. opposition and anticipated effects of the facility}

Supporters comprised relatively large proportions of managers and proprietors (88\%); clerical workers and salespersons and blue collar workers (75\%); blacks (83\%); males (76\%); and employed persons $(73 \%)$. Opponents constituted a majority only among farmers and farm workers (44\% supporters; $56 \%$ opponents). Other groups containing relatively large proportions of opponents included residents of farms ( $47 \%$ opponents), women ( $38 \%$ opponents) and unemployed persons ( $41 \%$ opponents). 
The finding that women tend more toward opposition to the nuclear facilities than do men is well established in other research. 95 The simplest explanation is that women saw some of the potential costs as relatively likely; and some of the potential benefits as relatively unlikely. Such perceptions among women, however, may reflect a general tendency toward conservative views on issues related to nuclear energy ${ }^{96}$ or a general tendency toward concern over the possibility of risks.

Among other groups that tended toward opposition to the nuclear plant, an explanation is fairly straightforward. Farmers believed that the prospect of economic benefits was relatively unlikely. Perhaps they expected their property taxes to rise with the increasing value of the 1 and. Residents of farms, who comprised about one-quarter of respondents, estimated the disruptive effects. of growth as relatively likely, including noise and congestion. For residents of farms near Hartsville, it does seem likely that the influx of workers could bring more noise and congestion. In brief, groups with disproportionate numbers of opponents saw the "trade" in relatively unfavorable terms, and tended to emphasize specific "costs."

Explanation for the disproportionately large numbers of supporters in some groups are not as clear-cut. Clerical workers and salespersons did believe economic benefits more likely, and hazards less likely, than did the remainder of the panel. However, blacks saw both costs and benefits as relatively likely. It is unclear why blacks would tend to see the trade as an extreme one. Perhaps as persons with relatively low incomes, they saw the effects of the nuclear plant as directly affecting their own circumstances. Reasons for support among managers and proprietors may include the possibility of increased business; although their expectations about the likelihood of such effects were about the same as those of the rest of the pane?.

The best general statement we can make is that demographic groups who leaned toward opposition seemed to see specific reasons for opposing the nuclear plant. These results suggest that it may be possible to predict opposition to nuclear facilities on the basis of potential costs seen by specific demographic groups. 


\subsubsection{Factual knowledge and sources of information about the facility}

The average respondent knew the correct answers for three or four of seven factual questions. Although we expected opposition of the facility to be associated with factual knowledge, we found no such relationship. Another recent study in Boston, however, did find greater opposition among people with relatively greater knowledge about nuclear power in general.97 The factual questions in the August survey focused on details of the Hartsville nuclear plant, however, and not on the broader issues related to nuclear power assessed in the Boston survey.

Respondents' primary sources of information were television and newspapers. Supporters' and opponents' sources of information differed only in that supporters tended to rely more on TVA. This finding is congruent with research evidence on the "selective exposure" hypothesis. ${ }^{98}$ If attitudes toward the nuclear plant do depend on information, the results of the August survey suggest that the most important facts would concern the likelihood of potential effects of the plant. Anything that changes peoples' views about the likelihood of very desirable effects (such as an increased supply of jobs) or very undesirable effects (such as the possibility of hazard) may affect support vs. opposition of the facility.

\subsubsection{The perceived quality of life}

Asked to rate the quality of life, respondents indicated a high degree of satisfaction with their lives, their neighborhoods, and most. amenities in the community. Their only complaint concerned the availability of housing. Ratings were fairly consistent and showed little change from January to August. Respondents saw housing as slightly more available in August, but said their neighborhoods were somewhat more noisy and crowded. Ratings of the yeneral quality of life declined slightly, but ratings of "life in Hartsville" remained stable. Although we found evidence of increased development between January and August 1975, the practically negligible decline in ratings of the quality of life could not be linked with plans to build the nuclear plant, because the decline in ratings occurred during a period of national economic recession. Construction had not begun in August, and changes in the quality of life may appear later. 
The most marked changed from January to August appeared in rating of neighborhoods as "stable vs. changing." In August, respondents still found their neighborhoods "stable," but significantly less so than in August.

\subsubsection{The relationship of perceived quality of life and attitudes toward the facility}

We expected opponents of the nuclear plant to experience a greater decline in ratings of the quality of life, but the evidence failed to support our hypothesis. Through August 1975, the impact of the proposed nuclear plant on the perceived quality of life in Hartsville must be seen as minimal for supporters and opponents alike.

\subsubsection{Potential consequences of subjective responses}

The objective consequences of attitudes and perceptions may take several forms. For example, people who experience discomfort as a consequence of changes that accompany the power plant--based on actual or imagined events--may simply leave the area. Increases in outmigration are easily measured. However, more subtle behavioral changes may occur as a result of stress. For example, a recent review of 83 empirical studies on the effects of population density suggests that overcrowding is associated under some circumstances with $i 11$ health and crime.99. Stress has been associated with impaired performance of tasks under some conditions. 100 If Hartsville residents do experience stress, they may show some of its effects. This possibility can be checked by monitoring the use of medical facilities, the incidence of accidents, absenteeism and turnover in jobs, and other appropriate "social indicators."101 These are tasks for future research.

Attitudes toward the nuclear plant may have implications for other types of behavior, 102 which may become increasingly important as the nuclear plant nears completion. For example, unfavorable attitudes may be associated with later outmigration or active, legal opposition of the facility. Future research in Hartsville may identify some of the consequences for overt behavior, if any, of various attitudes toward the nuclear plant. 
Such data represent a step toward the formation of a predictive model of social impacts, which may make possible the use of subjective responses as signals of subsequent actions.

For many residents, subjective reactions may have no obvious consequences. The reason appears in the well-documented human capacity for adaptation. 103 What may appear initially as a disturbing event may soon appear "natural" as it is reappraised and becomes familiar. The potential for adaptation represents another area for future investigation in Hartsville.

\subsection{Unanswered Questions About Subjective Responses to the Nuclear Plant,}

Even with fairly extensive information about subjective responses to the nuclear plant, several important questions remain for which the survey provides no answers. For example,

1. How accurate are citizens' perceptions about the effects of the nuclear plant?

If they are inaccurate, what might happen? The accuracy of residents' expectations remains to be seen, but if residents' fail to receive something desirable they now expect (such as more jobs) or receive something undesirable they expect not to happen (a prolonged shutdown of the plant, for example) the objective consequences may inslude actions hy segments of the community that we cannot anticipate from responses of the August survey.

2. How will TVA's plan for mitigating "âdverse socioeconomic impacts" affect the community?

It is possible that the mitigation plan will succeed in its aims. However, some residents may see themselves as treated unfairly. The potential for perceived "inequity"104 could mean dissatisfaction among certain segments of the community who may actively attempt lu ublain arrangements they see as more equitable. This problem requires more study.

3. How will the perceived quality of life in Hartsville change as construction proceeds?

These and other questions concern subsequent events in Hartsville and Trousdale County. Broader questions also arise, as described below. 


\subsection{Practical Implications}

As part of a program of basic research on social impact analysis, the August survey represents a source of data for the development of theory and the refinement of methods for studying social impacts. The findings may have practical implications, but we know of no precedent to suggest immediate applications for information derived from a survey of public views on a nuclear power plant.

The August survey revealed significant information about the preferences, concerns, evaluations, expectations, and information level of a sample of Hartsville residents about their community and the proposed plant. Potential users of the information, in addition to the researchers of this longitudinal study, include local officials and planners, the TVA, and other supporters and opponents of the project.

The survey also showed, in general terms, what consequences the respondents expect to accompany the nuclear plant. For example, they anticipate more jobs, better pay, and more public entertainment. If any of the general expectations are unrealistic, correcting the misconceptions will be important to both TVA and to local officials and residents. Discrepancies between perceptions, expectations, and reality will be particularly important for the success of the proposed plan for mitigating adverse impacts. For the findings of the August survey to assist this case, subjective responses among residents must be linked with objective conditions--not only the probable causes of adverse reaction, but the remedies as well. In this regard, it will be instructive to follow subjective reactions in future attitude surveys when responses will reflect evaluation of TVA's mitigation plan in operation. Since TVA's mitigation plan to deal with local socioeconomic effects caused by its construction activities is one of the most comprehensive to date, exceeded only by the Wheatland, Wyoming mitigation plans for a coal generating plant, 105 monitoring the effectiveness of and reactions to this plan will be particularly impoartant. The problem of mitigation of adverse effects is clearly a complex one. The utility of systematic data on subjective responses depends on other empirical data linking subjective responses with objective conditions. The next phase of the Hartsville work, now in progress, attempts these linkages. 
The findings of the survey may prove useful in making decision about public policy, but such applications require answers for several basic questions. First, to what extent should systematic surveys of public opinion contribute to the choice of construction sites for energy-generating facilities or the types of facilities? In the past, such decisions have often overlooked public opinion entirely, or depended on possibly unrepresentative views expressed at public hearings. (In the case of Hartsville, and other sites for power generating facilities, for example, TVA decided on the type of plant and chose the site without the benefit of data on public opinion.) A second unresolved question is, what kinds of information are needed, from what samples, if systematic surveys of public opinion are to contribute to decisions about sites for facilities? Another question is, if public opinion is to play a part in siting decisions, what degree of support is sufficient basis for a decision to construct the facility? Answers to these questions are clearly outside the scope of this report.

\subsection{Conclusions}

This survey has shown that even before the Hartsville nuclear power plant is constructed, residents have formed attitudes toward it and expectations about what will happen because of it. Objective socialpsychological impacts remain to be investigated, but subjective effects may signal other types of changes. 


\section{NOTES AND REFERENCES}

1. Other reports on the social impacts of the Hartsville nuclear plant include the following:

C. R. Schuller, J. R. Fowler, T. J. Mattingly, Jr., E. D. Sundstrom, J. W. Lounsbury, E, M. Passino, D. A. Dowell, and B. J. Hutton, Citizens' Fiews about the Proposed Hartsvilie Nuclear Power Plant: Preliminary Report of Potential Social Impacts, ORNL-RUS-3, Oak Ridge National Laboratory, Oak Ridge, Tenn., May 1975.

E. Passino and J. W. Lounsbury, "Sex Differences in Opposition to and Support for Construction of a Proposed Nuclear Power Plant." In L. M. Ward, et al. (eds.), The Behavioral Basis of Design: Selected Papers, pp. 180-188, Stroudsburg, Pa.: Dowden, Hutchinson, and Ross, 1976.

J. W. Lounsbury, E. D. Sundstrom, C. R. Schuller, T. J. Mattingly, Jr., and R. C. DeVault, "Toward an Assessment of the Potential Social Impacts of a Nuclear Power Plant on a Community: Survey of Residents Views." In K. Finsterbusch and C. P. Wolf (eds.), The Methodology of Social Impact Assessment, Stroudsburg, Pa.: Dowden, Hutchinson \& Ross, Inc., 1977 (in press).

E. Sundstrom, J. W. Lounsbury, C. R. Schuller, J. R. Fowler, and T. J. Mattingly, Jr., "Community Attitudes Toward a Proposed Nuclear Power Generating Facility as a Function of Expected Outcomes," Joumal of Community Psychology, 1977 (in press).

2. For a description of the rationale and results of the January survey, see C. R. Schuller, J. R. Fowler, T. J. Mattingly, Jr., E. D. Sundstrom, J. W. Lounsbury, E. M. Passino, D. A. Dowell, and B. J. Hutton, Citizens' Views about the Proposed Hartsvilze Nuclear Power Plant: A Preliminary Report of Potential Social Impacts, ORNL-RUS-3, Oak Ridge National Laboratory, Oak Ridge, Tenn., May 1975. In subsequent references to the January survey, we refer to this report simply as "Schuller, et al. (1975)."

3. For a discussion of the concept of attitude, see H. C. Triandis, Attitude and Attitude Change. New York: John Wiley and Sons, 1971. Also see W. McGuire, "Attitudes and Attitude Change," in G. Lindzey and E. Aronson (eds.), The Handbook of Social Psychology, Vol. 3, Reading, Mass.: Additon-Wesley, 1968. Of the two components (emotional response and beliefs), a person's emotional response appears to be more important. Throughout the present report, "attitude" refers to both components, but primarly to a person's emotional response, which is assumed to stem at least partly from beliefs. 
4. Recent evidence suggests that attitudes toward an object can be used to predict a variety of relevant, overt behaviors. See M. Fishbein and I. Ajzen, "Attitudes toward Objects as Predictors of Single and Multiple-Behavioral Criteria," Psychological Review, 81 (1), 1974, pp. 59-74. See also R. H. Weigel and L. S. Newman, "Increasing Attitude Behavior Correspondence by Broadening the Scope of Behavioral Measure," Joumal of Personality and Social Psychology, 33 (6), pp. 793-802, 1976.

5. R. Mason, F. D. Faulkenberry, and A. Seidler, The Quality of Life as Oregonians See It. Technical. Report, Oregon. State University, 1976. jee also J. B. Lansing and R. W. Marans, "Evaluation of Neighborhood nuality," American Institute of Planners' Journal, 75, pp. 195-199, 1969.

6. F. Andrews and S. Withey, "Developing Measures of Perceived Life Quality: Results from Several National Surveys," Social Indiaatoro Research, 1: pp. 1-26; 19.74.

7. See the following: L. M. Bronfman and T. J. Mattingly, Jr., "Critical Mass: Politics, Technology and the Public Interest, "Nuclear Safety, 17(5) Sept.-Oct. 1976, p. 539-549;

See also P. Gwynne, J. Bishop, and S. Michaud, "How Safe is Nuclear Power?" Newsweek, April 12, 1976; D. J. Rose, P. W. Walsh, and L. L. Leskovjan, "Nuclear Power - Compared to What?" American Scientist, 64, pp. 291-299, 1976.

8. Louis Harris and Associates, Inc., A Sumey of Public and Lëadership Attitudes Toward Nuclear Power Development in the United States. Conducted for Ebasco Services, Inc., New York, August 1975.

9. "The Great Nuclear Debate," Time, December 8, p, 36, 1975.

10. A. M. Weinberg, "The Maturity and Future of Nuclear Energy," American Scientist, 64, pp. 16-21, 19, 1976.

11. Schuller, et al. p. 39, 1975.

12. See for example, K. Gergen, et a1., Social Psychology: Explorations in Understanding, Del Mar, Calif.: CRM Books, 1974.

13. For a review of the theoretical apprnach and its empirical support., see T. Mitche11, "Expectancy Models of. the Job Satisfaction, Occupational Preference, and Effort: A Theoretical, Methodological, and Empirical Appraisal," Psychological Bulletin, 81 (12), pp. 1053-1077, 1974. 
14. E. D. Sundstrom, J. W. Lounsbury, C. R. Schuller, J. R. Fowler, and T. J. Mattingly, Jr., "Community Attitudes Toward a Proposed Nuclear Power Generating Facility as a Function of Expected Outcomes," Journal of Community Psychology, 1977 (in press).

15. As indicated in Section 5, the August survey asked respondents to estimate the likelihood and desirability of 27 specific effects the plant could potentially have on Hartsville. Ratings of likelihood in August were made on a 7-point scale, whereas in January they were made on a 5-point scale. In assessing desirability in January, we asked respondents to identify effects they "would not like to see happen.". In August we used a 7-point scale. The more precise measurement of desirability in August allowed the use of weighted estimates of likelihood (likelihood $x$ desirability), which were expected to show a stronger relationship with attitudes. See E. Sundstrom, et al., "Acceptance of a Nuclear Plant and Expectations about its Effects: Applications of the Expectancy-Valence Model." Unpublished report, Oak Ridge National Laboratory, 1977.

16. For a discussion of "investment" or "ego-involvement;" see M. Sherif and C. Sherif, Social Psychology, New York: Harper and Row, 1968.

17. The idea that people seek sources of information consistent with their own attitudes is called the "selective exposure hypothesis," and it has been studied extensively by social psychologists. Research evidence indicates that selective exposure occurs only under certain conditions. See J. Freedman and D. Sears, "Selective Exposure" in L. Berkowitz (ed.) Advances in Experimental Social Psychology, Vol. 2, New York: Academic Press, pp. 57-97, 1972.

18. Harris, p. 89, 1975.

19. A. Mazur, "Opposition to Technological Innovation," Minerva, 13, pp. 58$81,1975$.

20. The January survey revealed a greater tendency toward opposition to the nuclear facllity among women than among men. See E. Passino and J.W. Lounsbury, "Sex Differences in Opposition to and Support for Construction of a Proposed Nuclear Power Plant," in L. M. Ward, et al., (eds.) The Behavioral Basis of Design: Selected Papers, pp. 180-188, Stroudsburg, Pa.: Dowden, Hutchinson, and Ross, 1976. See also Schuller, et al., p. 45, 1975 .

21. As shown in Schuller, et a1., p. 43, 1975 respondents in the January survey with fewer than 12 years of education tended more toward support of the facility than high school graduates. However, Harris, p. 89, 1975, reported that those with less than 12 years of education tended to say they were undecided, while college graduates tended to express an opinion and to contain larger proportions of both supporters and opponents of nuclear energy. 
22. See Schuller, et a1., p. 44, 1975.

23. See Schuller, et a1., p. 46, 1975.

24. We measured changes in the perceived quality of life in Hartsville by comparing ratings made in August with those made in January. However, if we did find changes our confidence that the nuclear plant caused the changes would be limited unless we could compare the ratings in Hartsville with ratings by residents of a comparable community where no nuclear plant is planned. The changes we observed in Hartsville could conceivably represent (a) society-wide trends that appear not only in Hartsville but in similar communities, or (b) the results of changes in Hartsville besides those associated with the power plant. However, the stability of conditions in Hartsville during the last 100 years makes the nuclear plant a plausible agent of observed changes. (See D. T. Campbell and J. C. Stanley, Experimental and Quasi-Experimental Designs for Research, Chicago: RandMcNa11y, 1966.)

25. See Schuller, et al., pp. 1-7, 1975. See also Energy Division Annual Progress Report, ORNL-5124, Oak Ridge National Laboratory, April 1976.

26. The term "psychological" means that the analysis focuses on the behavior and experience of individuals. Psychological effects are changes in the overt behavior or subjective experiences of individuals. In the current project, we examine psychological variables that might respond to changes in the physical environment, such as perceptions of the quality of life and attitudes. The terin "psychological" has other meanings. Psychologists study such things as motivation, the development of personality, assessment of personality, and mental health. See, for example, G. Kimble, N. Garmezy, and N. Zigler, Principles of General Psychologu. 4th Ed., New York.; Ronald Press; 1974. We consider these issues tangential to the study of social impacts of energy-generating activities.

27. See the following: M. Shields, "Social Impact Studies: An Expository Analysis," Environment and Behavior, 7 (3), pp. 265. 284, 1975. C. P. Wolf, "Social Impact Assessment: The State of the Art," in n. Carson (ed.), EDRA 5: Man-Envirunluerl Irliterections, Vol. 2, Social Impact Assessment. Milwaukee, Wis: Environmental Design Research Association, pp. 1-44, 1974; E. Peelle, "Social Effects of Nuclear Power Plants," in D. Carson (ed.), EDRA-5: Man-Enuizonment Interactions, Vol. 2, Milwaukee, Wis: Environment Design Research Association, 1974.

28. For a discussion of the concept of stress and evidence related to its occurrence, see R. S. Lazarus, Psyohological stress and like Coping Process, New York: McGraw-Hill, 1966.

29. See, for example, R. Babbie, Survey Research Methods, Belmont, Calif.: Wadsworth, 1973. 
30. See the following: E. Webb, D. T. Campbell, R. D. Schwartz, and L. Sechrest, Unobtrusive Measures: A Survey of Non-Reactive Research in Social Science, Chicago: Rand-McNally, 1966; N. Denzin, The Research Act, Chicago: Aldine, 1970.

31. A. Campbe11, P. E. Converse, W. E. Miller, and D. E. Stokes, The American Voter, New York: Wiley, 1960.

32. U.S. Bureau of the Census, Census of Populations: 1970, General Population Characteristics. Final Report PC-(i)-B-44 Tennessee, Washington, D.C., U.S. Government Printing Office, 1971.

33. Trousdale County Area Development Committee, Overazz Economic Devezopment Program, Technical Report, Trousdale County, 1972.

34. U.S. Bureau of the Census, Census of. Populations: 1970, General Population Characteristics. Final Report PC-(1)-B-44 Tennessee, Washington, D.C., U.S. Government Printing Office, 1971.

35. Tennessee Department of Public Health, Office of Health Planning, Health in Tennessee: A Statistical Overview, Technical Report, Nashville, Tenn., July 1973.

36. Schuller, et al., p. 70, 1975.

37. In 1974, the Atomic Energy Commission was reorganized. Research and development related to energy are now performed by the Energy Research and Development Administration (ERDA). A separate and independent regulatory agency, the Nuclear Regulatory Commission (NRC), was created and given responsibility for insuring the safety of nuclear installations.

38. U.S. Nuclear Regulatory Commission, Office of Nuclear Reactor Regulation, Final Environmental Statement Related to Construction of Hartsville Nuclear Plants of the Tennessee Valley Authority. Docket No. STN50-518 through STN50-521, Document No. NUREC-75/039, Appendix D, 1975. We refer to this document as the "NRC Final Environmental statement."

39. NRC Firnal Environmental statement, p. 9-4.

40. NRC Final Environmental statement, p. 1-3.

41. NRC Final. Enviommental statement, p. i.

42. Tennessee Valley Authority, Final Environmental Statement, Hartsvilze Nuclear Plant, Vol. 1, p. 4-1; May 1975. (We refer to this document as "TVA Final Environmental Statement.")

43. These estimates were given by Richard Swisher, the representative of TVA in Hartsville, in a telephone conversation on April 20, 1976. 
44. NRC Final Environmental Statement, p.1-1.

45. NRC Final Environmental Statement, p. 4-20.

46. Personal communication, Richard Swisher of TVA, October 1976.

47. Atomic Safety and Licensing Board, Nuclear Regulatory Commission, Tennessee Valley Authority, Hartsville Nuclear Plant, Partial Initial Decision on Environmental and Site Suitability Aspects of the Facility, Making Determinations of Fact and Law Requisite for the Issuance of a Limited Work Authorization, LBP-76-16, Apri1 20, 1976.

48. A panel design involves surveying a "panel" of respondents at two or more times. See the book by Campbel1, et al., cited in Note 31 .

49. For the Town of Hartsville we used The Directory and Property Numbering System, Tennessee State Planning Office, March 1974. For Trousdale County, we used The Trousdale County Directory, Citizens Bank of Hartsville, undated. See Schuller et al., p. 67, 1975.

50. Schuller, et a1., p. 68, 1975.

51. The August survey coincided with the tobacco-picking season, during which many Trousdale Countians work long hours. The main reason given for inability to reinterview a respondent was that he or she was picking tobacco. We examined the characteristics of the "dropouts" (people who could not or would not be reinterviewed in August) to see whether they differed from the 288 people who were interviewed twice. We used chi-squared tests (see, for example, D. Champion, Basic Statistics for Social Research, Scranton, Pa.: Chandler, 1970) to compare the dropouts with the members of the panel. Results showed no significant differences in the distributions of sex, marital status, race, number of years in the county, age, or occupation. However, the "dropouts" had significantly fewer years of education ( $x^{2}=14.56, d f=4$, $p<.01)$. Of those who could not or would not be reinterviewed, $24 \%$ had fewer than seven years of school, compared with $7 \%$ of the panel. This finding probably reflects the loss of all of the farm laborers who pariticipated in the January survey.

52. A new sample of 122 residents was also selected in August; 97 were interviewed, 21 refused to be interviewed, and four could not be located. There were two main reasons for the new sample. First, as described in Section 3.3, the panel of 350 was unrepresentative in terms of race-there were too few blacks. To remedy this problem, we stratified the new sample in terms of race so that when we later added it to the panel, the resulting group would have the same ratio of black to white residents as the county population in 1970. A second reason for the new sample was to replace members of the original sample who could not be reinterviewed. For the present report, only the responses of the panel of 288 people are presented, including the changes from January to August. For our next survey (planned after the beginning of construction of the plant) the new sample of 97 persons will be merged into the panel. 
53. We asked whether respondents would have answered the questions different1y aloud; 97\% said "no."

54. These data are based on the panel of 288 people.

55. See C. H. Backstrom and G. Hirsch, Survey Research, Northwestern University Press, 1963.

56. See Note 51 .

57. Tennessee Department of Public Health, Office of Health Planning, Health in Tennessee: A Statistical Overview, Technical Report, Nashville, Tenn., July 1973.

58. U.S. Bureau of the Census, Census of Populations: 2970, Generai Population Characteristics, Final Report PC-(1)-B-44 Tennessee, Washington, D.C: U.S. Government Printing Office, 1971.

59. The distributions of age among the panel and the population of the county were not significantly different, but the panel tended.slightly toward over-representation of people near the average age, and underrepresentation of people younger than 30 years of age or older than 70 years of age.

60. We used the Statistical Package for the Social sciences, described in N. H. Nie, et al., S.P.S.S., New York: MCGraw-Hill, 1970.

61. "Consistency" is defined as the predictability of an individual's response from earlier responses by the same person. If most people made the same response in January and August or if most people's responses changed in the same way, their responses would be called consistent. For example, if neighborhoods are rated on "attractiveness" on a 7-point scale, and if most people's ratings were approximately the same at both times, their responses would be called consistent. It is possible for the average response of the whole sample to remain the same when individual responses are inconsistent. Before making a confident interpretation of data regarding the average response, it is necessary to show a reasonably high degree of consistency in individual responses. Inconsistency of individual response could mean that scores contain errors of measurement or that the response being measured is inherently unstable.

62. We calculated our sampling error as $6 \%$. Our calculations employed a 95\% confidence interval, based on "yes" or "no" answers to the question of permitting the nuclear plant. A sampling error of $6 \%$ with a "confidence" of $95 \%$ means that of 100 similar samples drawn from the same population, in 95 of them the percent answering "yes" would 1 ie between $63 \%$ and $75 \%$. Procedures for making these calculations appear in W. G. Cochran, Sampling Techniques, 2nd. ed., New York: Wiley, pp 18-47, 1973. The calculations assume that the sample is representative, but it is in some respects not representative. Even though we attempted to select a random sample in January, there were "refusals" 
and "dropouts." We have evidence that the panel in August was better educated than the population of the county and contained too few blacks, as described in Section 3.3. Therefore, our estimate of sampling error could itself be slightly in error.

63. The distribution for January given here is based on the panel of 288 people who completed both surveys. The results of the January survey reported in Schuller, et al., 1975 are slightly different because they are based on the original sample of 350 people.

64. The higher proportion of people who expressed opinions in August may reflect the elimination of "don't know" as an explicit alternative answer for the "permit construction" question in August. The question called for either a favorable or unfavorable response. Respondents who were uncertain or unwilling to take a position could only write their answer or leave the question blank. A second modification in August. involved answering the question privately instead of aloud, which may have meant that some respondents felt less inhibited in giving their answers, although $97 \%$ said they would have answered the same way aloud.

65. For readers unfamiliar with this statistic, the Pearson product moment correlation coefficient, or Pearson $r$, indicates the degree of linear relationship between two variables measured among the same set of individuals. (Each individual has a score on both variables.) The Pearson $r$ indicates the extent to which the values of one variable can be used to predict values of the second variable. Pearson $r$ varies between -7 and +1 . A value of zero indicates that there is no Tinear relationship. A positive value indicates a direct, linear relationship in which higher values of one variable are associated with higher values of the other variable. The closer $r$ is to 1.0, the stronger the relationship, and the smaller the error in predicting one variable from the other. For example, if $r$ for lanuary=August ralings were .30 , the relationship is not as strong as if the $r$ were .60 . With an $r$ of .30 , there would be more error involved in using one variable to predict the other. If $r$ assumes a negative value, it indicates an inverse relationship--higher values of one variable are associated with Tower values of the other. The closer $r$ is to -1.0 , the stronger the inverse relationship is. It is possible to test the statistical significance of a value of $r$. By convention, "significant" means that the value would occur by chance alone fewer than 5 times in 100 . We indicate this by "p<.05," which means "probability of less than 5 in 100 by chance alone." Similarly, "p<.01" means that the value would occur fewer than one time in 100 by chance. (For a discussion of Pearson $r$ and its test of significance, see, for example, W. Hays, Statistics. New York: Holt, Rinehart, and Winston, 1963.) For the Pearson $\underline{r}$ for responses to the "permit construction" question in January and August, we used a 5-point scale for January ("definitely yes" = 1 and "definttely no" = 5) and a 4-point scale in August ("definitely yes" = 1 and "definitely no" = 4. People who made no response were excluded). 
66. See, for example, M. Sherif and C. Sherif, Social Psychology, New York: Harper and Row, 1968.

67. The "intensity" of an attitude can have two meanings: (a) the extent to which a person's view is on one side of an issue, or its extremity; and (b) emotional investment, or "strength of feeling." (See W. Scott, "Attitude Measurement," in G. Lindzey and E. Aronson, eds., The Handbook of Social Esychology, Vol. II, Reading, Mass.: Addison-Wesley, 1968.) The two dimensions can be viewed as independent. A person can have a moderate attitude and feel very strongly about it, or have an extremely "pro" or "anti" attitude with little emotional investment. However, extreme attitudes are usually associated with strong feelings about the issue. (See the book by Sherif and Sherif cited in Footnote 65.) For the present report, "intensity" means both "extremity" and "emotional investment."

68. The list of effects used in January was modified for the August survey in light of answers to open-ended questions in January (see Schuller, et al., pp. 48-49, 1975). The following new effects were included in August: better schools, more billboards, more stores and shopping areas, foggy days, housing shortages, increased land values, and more recreation areas. We eliminated some effects we used in January: community stays the same, dating with workers, crowding in recreational areas, and crowding in shopping areas. The wording of some effects was changed slightly: "water pollution" was changed to "pollution of 0ld Hickory Lake;" "lower taxes" was changed to "increased taxes;" "more tourists" was changed to "town becomes a tourist attraction;" "public recognition of the town" was changed to "state and national recognition of the town;" "accidents or sabotage at the plant" was changed to "sabotage at the plant;" and "better pay" was changed to "better-paying jobs."

69. In January, ratings were based on a 5-point scale: "very likely," "likely," "perhaps," "unlikely," and "very unlikely." In August, the scale was the same except that two extreme categories were added: "certain to happen" and "almost impossible." The result was a 7-point scale in August.

70. Factor analysis is a family of statistical procedures for identifying independent groups of variables within which the variables are correlated with one another. There are many procedures now in use. They all begin with a matrix of correlations and identify the groups whose variables are intercorrelated. The groups are called factors, and they are extracted in order of the amount of "common variance" contained in each. The first factor "accounts for" the greatest proportion of the variance. We employed one of the simplest procedures, a principal-components factor analysis, and we used varimax rotation with no iterations. We extracted orthogonal factors with eigenvalues of 1.0 or higher. In assigning effects to the factors, we used the highest factor loading, which exceeded .50 for all but two of the 27 effects. For a relatively nontechnical description of factor analysis, 
see R. J. Rumme1, Understanding Factor Analysis, Evanston, I11.: Northwestern Unviersity Press, 1970. For a more mathematical treatment, see H. H. Harmon, Modern Factor Analysis, Chicago, I11.: University of Chicago Press, 1967.

71. The results of the factor analysis were as follows:

\begin{tabular}{|c|c|c|c|c|c|c|}
\hline \multirow[b]{2}{*}{ Effect } & \multirow[t]{2}{*}{ Communality } & \multicolumn{5}{|c|}{ Factor Loadings } \\
\hline & & $I$ & II & III & IV & V \\
\hline \multicolumn{7}{|c|}{$\begin{array}{l}\text { Factor I } \\
(23 \% \text { of variance }) \\
\end{array}$} \\
\hline $\begin{array}{l}\text { Traffic congestion } \\
\text { More taverns } \\
\text { Crowded schools } \\
\text { Increased noise } \\
\text { Increased crime } \\
\text { Drugs in schools } \\
\text { Increased taxes } \\
\text { Shortage of housing }\end{array}$ & $\begin{array}{l}.51 \\
.57 \\
.52 \\
.55 \\
.61 \\
.47 \\
.43 \\
.53\end{array}$ & $\begin{array}{l}. \frac{.69}{.68} \\
. \frac{67}{68} \\
. \frac{68}{.65} \\
. \frac{56}{56} \\
. \frac{50}{0}\end{array}$ & $\begin{array}{r}-.16 \\
.22 \\
.23 \\
.22 \\
.42 \\
.36 \\
.33 \\
.19\end{array}$ & $\begin{array}{r}.03 \\
.06 \\
-.06 \\
.18 \\
-.03 \\
.07 \\
.00 \\
-.19\end{array}$ & $\begin{array}{r}.08 \\
.23 \\
.05 \\
.00 \\
.03 \\
-.15 \\
.09 \\
.16\end{array}$ & $\begin{array}{r}.00 \\
-.10 \\
-.03 \\
.09 \\
.00 \\
-.00 \\
.06 \\
.42\end{array}$ \\
\hline \multicolumn{7}{|c|}{$\begin{array}{l}\text { Factor II } \\
(19 \% \text { of variance })\end{array}$} \\
\hline $\begin{array}{l}\text { Kadiation hazard } \\
\text { Air pollution } \\
\text { Sabotage at plant } \\
\text { Foggy days } \\
\text { Pollution of lake }\end{array}$ & $\begin{array}{l}.69 \\
.76 \\
.53 \\
.59 \\
.64\end{array}$ & $\begin{array}{l}.17 \\
.41 \\
.03 \\
.24 \\
.41\end{array}$ & $\frac{.81}{. \frac{76}{.72}} \cdot \frac{70}{.64}$ & $\begin{array}{r}.02 \\
-.03 \\
.03 \\
-.09 \\
-. .16\end{array}$ & $\begin{array}{r}-.07 \\
.00 \\
-.04 \\
.13 \\
-.17\end{array}$ & $\begin{array}{r}.00 \\
.02 \\
-.12 \\
-.08 \\
.04\end{array}$ \\
\hline \multicolumn{7}{|c|}{$\begin{array}{c}\text { Factor III } \\
(6 \% \text { of variance) }\end{array}$} \\
\hline $\begin{array}{l}\text { More stores/shopping } \\
\text { More entertainment } \\
\text { More recreation areas } \\
\text { More billboards } \\
\text { Increased business }\end{array}$ & $\begin{array}{l}.75 \\
.53 \\
.59 \\
.42 \\
.62\end{array}$ & $\begin{array}{r}.12 \\
-.09 \\
-.14 \\
.19 \\
.12\end{array}$ & $\begin{array}{r}-.07 \\
-.14 \\
-.05 \\
.31 \\
-.12\end{array}$ & $\frac{.79}{\cdot \frac{.62}{58}} \cdot \frac{53}{.53}$ & $\begin{array}{r}.13 \\
.30 \\
.48 \\
-.05 \\
.27\end{array}$ & $\begin{array}{l}.29 \\
.09 \\
.01 \\
.06 \\
.48\end{array}$ \\
\hline \multicolumn{7}{|c|}{$\begin{array}{c}\text { Factor IV } \\
(4 \% \text { of variance })\end{array}$} \\
\hline $\begin{array}{l}\text { Tourist attraction } \\
\text { Recognition/town } \\
\text { Meet new people } \\
\text { Industrial development }\end{array}$ & $\begin{array}{l}.61 \\
.60 \\
.51 \\
.55\end{array}$ & $\begin{array}{r}.07 \\
.02 \\
.27 \\
-.08\end{array}$ & $\begin{array}{r}.05 \\
.06 \\
=.15 \\
-.05\end{array}$ & $\begin{array}{l}.24 \\
.10 \\
.08 \\
.40\end{array}$ & $\begin{array}{l}.74 \\
.67 \\
.59 \\
.62 \\
\end{array}$ & $\begin{array}{l}.02 \\
.36 \\
.34 \\
.30\end{array}$ \\
\hline \multicolumn{7}{|c|}{$\begin{array}{c}\text { Factor } V \\
(1 \% \text { variancc }) \\
\end{array}$} \\
\hline $\begin{array}{l}\text { Increased land value } \\
\text { Morc johs } \\
\text { Better paying jobs } \\
\text { Better schools }\end{array}$ & $\begin{array}{l}.55 \\
.0 .3 \\
.48 \\
.48\end{array}$ & $\begin{array}{r}.14 \\
-.03 \\
-.16 \\
-.36\end{array}$ & $\begin{array}{r}.01 \\
.00 \\
-.16 \\
-.22\end{array}$ & $\begin{array}{l}.06 \\
.39 \\
.30 \\
.12\end{array}$ & $\begin{array}{l}.03 \\
.30 \\
.24 \\
.33\end{array}$ & $\frac{.72}{. \frac{72}{63}} . \frac{.42}{42}$ \\
\hline \multicolumn{7}{|c|}{ Other effect } \\
\hline Cheap electricity & .40 & .41 & $-.07=$ & .33 & .31 & -.12 \\
\hline
\end{tabular}

In the fartor analysis, "foggy days" was in Factor II, cilled "hazards," even though it is not clearly a hazard. We tried several other types of factor analysis, and the results were similar for all of them. Factors I and II were consistent; the "economic" groups (III, IV, and V) sometimes changed by one or two effects. 
72. It is possible that the use of fixed-choice questions about the likelihood of effects suggested answers the respondents might not otherwise have given. To examine this possibility we included an open-ended question before asking for the ratings. The question was, "Now what changes, if any, do you think the proposed plant might bring to Hartsville-Trousdale County?" Most respondents volunteered two or three "changes." (The average was 2.6.) A total of 743 responses were made, which we have grouped as follows:

Disruptive effects of growth (crowding, congestion, overload of services, etc.)

Economic benefits (more jobs, industry, stores, etc.) $28 \%$

Hazards

Other effects (better government, non-specific change, etc.)

The "changes" volunteered most often - economic growth and disruptive effects of growth - correspond with four of the five groups of effects that emerged from the responses to the fixed-choice questions. Hazards were mentioned very infrequently.

73. A comparison between January and August groupings or factors is somewhat misleading because the two lists of effects were not the same. However, while the list of 27 possible effects in the August survey had only 20 effects in common with the list of 24 presented in the January survey, the groups of effects in January were similar to the groups in August. There were five groups in both January and August, including hazards, disruption, and three groups of economic effects. The "hazards" group in August included all four of the effects in the "hazards" group of January. Similarily, the "disruptive effects" group in August included all five of the effects in the corresponding group in January. The three groups of economic effects only partly corresponded with those of August. The "outside attention" group was essentially the same, but what we called "economic growth" in January included effects that appeared in both the "increased business" group, such as industrial development and the effects that appeared in the "economic benefits" group in August, such as more jobs.

74. The use of a 7-point scale was new in August. In the January survey, we simply asked respondents to indicate which of the effects they "would not like to see happen." These were labeled "undesirable."

75. For the January survey, when a respondent failed to mention an effect as something he or she would "not like to see happen" we assumed the effect was either desirable or neutral to the respondent. 
76. The t-test is a statistical test used to decide whether the means or averages of two groups are significantly different. The difference between the two groups means is compared against the variability within the groups. A t-value reaches significance when the difference between the means is large compared with the variability within the groups. "Significant" means $p<.05$, as described in Note 65. (See, for example, W. Hays, Statistics, New York: Holt, Rinehart, and Winston, 1963.) When using independent t-tests, we routinely report the $t$-value based on separate variance estimates using a twotailed test.

77. Multiple regression analysis is based on the correlations between a variable to be predicted, called the "criterion," and each variable to be treated as a possible predictor. The analysis yields an equation that specifies the combination of values of the predictors that reproduces values of the criterion with least error. We used simple mulliple regression, with predictor variables entered in order of the increment of unique predictable variance in criterion scores contributed by each one. The first predictor accounts for the largest proportion in variance, the second predictor accounts for the next largest proportion of variance not redundant with the variance predicted by the first predictor, and so on. In reporting the results of regression analyses, we list only the predictors associated with significant proportions of variance, as indicated by F-tests. For a description of the statistical basis for multiple regression, see F. Kerlinger and E. Pedmayer, Muztiple Regression in Behavioral Research, New York: Holt, Rinehart and Winston, 1373. Also see J. Overall and C. Klett, Applied MuZtivariate Analysis, New York: McGraw-Hil1, 1973.

78. The predictors were based on the five likelihoud factors. We calcu. lated factor scures by simply adding the estimates of likelihood for the effects in the factor (or group) and dividing by the number of effects, yielding an average estimate of likelihood. This procedure did not preserve the independence of the factors. Average estimates of 1 ikelihood were intercorrelated as follows:

\begin{tabular}{|c|c|c|c|c|c|c|}
\hline & Factor & $\mathrm{I}$ & I I & I I I & IV & V \\
\hline $\begin{array}{l}\text { I. } \\
\text { II. } \\
\text { III. } \\
\text { IV. } \\
\text { V. }\end{array}$ & $\begin{array}{l}\text { Disruptive effects } \\
\text { Hazards } \\
\text { Increased Business } \\
\text { Outside Attention } \\
\text { Economic Benefits }\end{array}$ & $\begin{array}{l}- \\
.56 \star * \\
.09 \\
.14 \\
-.08\end{array}$ & $\begin{array}{l}- \\
-.10 \\
-.08 \\
-.26 \star \star\end{array}$ & $\begin{array}{l}- \\
.55^{* \star} \\
.52^{* *}\end{array}$ & $.57 \star \star$ & - \\
\hline
\end{tabular}

$\star *<.001$. 
Estimates of the likelihood of undesirable effects were highly correlated (Factors I and II), as were estimates of the likelihood of desirable effects (Factors III, IV, and V).

79. The use of a composite index is based on the idea that composite scores are more reliable than scores based on single items (see J. P. Guilford, Psychometric Methods, New York: McGraw-Hi11, 1954). To form the composite, we scaled from 1.0 to 5.0 the responses to "distance from home" question. A score of 1.0 referred to the closest category (see Table 4.3). The "permit construction" question was scaled from 1.0 to 4.0 with 1.0 indicating "definitely yes" and 4.0 indicating "definitely no." These two scaled scores were transformed into z-scores (the number of standard deviations from the mean) and added to form a new score for each respondent ( $z$-scores have a mean of zero and a standard deviation of 1.0).

The use of $z$-scores insured that the composite would reflect equally its two components. The composite index had a mean of zero and ranged from -2.41 (strong support) to 3.00 (strong opposition), with a standard deviation of 1.83 . The composite index correlated .92 $(p<.001)$ with the "distance from home" and "permit construction" questions.

80. A chi-squared test of independence is used to test the relationship between two (or more) variables whose values are mutually exclusive categories (e.g., the variable sex has two categories). A significant chi-squared means that within some or all of the categories of one variable, the frequency distribution of the other variable is different from what would have been expected by chance if the variables were independent. For example, there were significantly more male supporters and fewer female supporters than would be expected by chance alone given that $69 \%$ of the panel were supporters. (See D. Champion, Basic Statistics for Social Research, Scranton, Pa.: Chandler Publishing Co., 1970.) The chi-squared tests in this section are based on the dichotomy of supporters vs. opponents. To simplify, we did not distinguish between answers of "definitely yes" and "probably yes" or "definitely no" and "probably no" to the question about permitting construction of the plant. (In many cases the chisquared test using all four responses would have been inappropriate anyway because of small cell sizes.)

81. These scores were obtained only for the respondents in a category who had answered the "permit constructior." question. (Three people did not answer; they were excluded from this analysis.)

82. The questions were based on information that had been released to the public by TVA. We were concerned that the questions not be seen as a "test," so we prefaced them this way:

Now, we have a few questions about the proposed nuclear power plant. With all that is written about the project, we'd like to get a general idea of what facts, if any, are of such interest to the people that they would remember them. If you don't know an answer, that is just as helpful 
to us as if you did. If you aren't sure, but have a vague idea, please just say what you think it might be. I' 11 read you the questions and then show you a list of answers to choose from.

83. Schuller, et al., pp. 15-36, 1975.

84. The format adopted for this set of questions is based on the "semantic differential." See D. R. Heise, "The Semantic Differential and Attitude Research," in G. F. Summers (ed.), Attitude Measurement, Chicago, I11., Rand-McNally, 1970.

85. Because the average ratings made in January were so high, it is possible that the slight decline in August reflects "regression toward the mean" (see D. T. Campbel1 \& J. Stanley, Experimental and QuasiExperimental Design for Research. Chicago; Rand-McNally, 1966). If such regression is present, the decline in ratings could be partly or wholly an artifact.

86. H. Cantril, The Pattern of Human Concem, New Brunswick, N.J.: Rutgers University Press, 1966.

87. Schuller, et a1., p. 39, 1975.

88. R. Kasperson, G. Berk, D. Pijawka, A. Sharaf, and I. Wood, Nuczear Energy, Local Conflict, and Public Opposition. Review draft of technical report for Project RARE (Risk. Assessment of Rare Events), Clark University, Worcester, Mass., August 1976. Cited by permission. We shall refer to this report as "Kasperson, et al., 1976.")

89. J. Haskins, A Survey of Opinions Toward the Proposed Hartsvizle Nucleare Plont., Technical Report, Communications Research Center, University of Tennessee, Knoxville, June 1975 (referred to as "Haskins, 1975").

90. Sundstrom, et al., 1977 (in press).

91. Haskins, p. 32, 1975.

22 J. J. Giliniore, "Buull Tuwrs May Hinder Enerğy Kesource Development, Science, 191, pp 535-540, 1976.

93. Kạperson, et a $1 ., p .36,1975$.

94. See the article by Mitchell cited in Note 13.

95. See the research cited in Notes $19,20,88$, and 89 See al so B.
Greer-Wooten and L. Mitson, Nuctear Power and the Canadian Publio Toronto: Institute for Behavioral Research, York University, 1976. 
96. M. J. Rosenberg, "Images in Relation to the Policy Process: American Public Opinion on Cold-War Issues," in H. C. Kelman (ed.) International Behavior, New York: Holt, Rinehart \& Winston, 1966.

97. Kasperson, et a1., pp. 38-39, 1976.

98. See Note 17.

99. E. Sundstrom, "Crowding as a Sequential Process: Review of Research on the Effects of Population Density on Humans," in A. Baum and Y. Epstein (eds.), Human Response to Crowding, Hillsdale, N.J.: Eribaum, 1977 (in press).

100. See, for example, D. Glass and J. Singer, Urban Stress: Experiments in Noise and Social Stressors, New York: Academic Press, 1972.

101. J. R. Newbrough and R. M. Christenfeld, Community Mental Health Epidemiology: Nashvizle. Technical Report, Center for Community Studies, George Peabody College for Teachers, Nashville, Tenn., 1974.

102. See Note 4. See also M. Fishbein and I. Ajzen, Belief, Attitude, Intention, and Behavior, Reading, Mass.: Addison-WesTey, 1975.

103. J. Wohlwill, "Human Adaptation to Levels of Environmental Stimulation," Human Ecology, 2, pp. 127-147, 1974.

104. L. Berkowitz, Advances in Experimental Social Psychology, Vol. 6, Equity Theory. New York: Academic Press, 1976.

105. See E. Peelle, Intermalizing Social Costs in Power Plant Siting: Some Examples for Coal and Nuclear Plants in the United States, presented at the American/European Nuclear Society Meetings, Washington, D.C., November 17, 1976, for a comparative discussion of mitigation plans for the Hartsville, Skagit, and Wheatland generating plants. 


\section{THIS PAGE}

\section{WAS INTENTIONALLY \\ LEFT BLANK}


ORNL/TM-5801

Internal Distribution

1. S. E. Beall

2. D. J. Bjornstad

3. C. R. Boston

4. B. H. Bronfman

5. R. S. Carlsmith

6. L. G. Berry

7. C. Chern

8-17. L. J. Costomiris

18. T. Cowan

19-28. R. C. DeVault

29. W. Fulkerson

30. E. A. Hirst

31. Norman Hinkle

32. M. J. Ketelle

33. C. R. Kerley

34. R. B. Honea

35. A. S. Loebl

36-46. J. W. Lounsbury

47. L. A. Martin

48-57. T. J. Mattingly, Jr.

58. J. McWherter

59-68. E. M. Passino
69-78. E. Peelle

79. H. Postma

80. B. J. Purdy

81. A. S. Quist

82. P. L. Rice

83. M. W. Rosentha?

84. T. Row

85. R. M. Rush

86. M. A. Shields

87. R. L. Spore

88-97. E. D. Sundstrom

98. R. E. Thoma

99. A. H. Voelker

100. D. Vogt

101. H. E. Zittel

102-103. Central Research Library

104. Document Reference Section

105-106. Laboratory Records

107. Laboratory Records (RC)

108. ORNL Patent Office

109-554. Regional and Urban Studies

\section{External Distribution}

555. Director, Research and Technical Support Division, ERDA-ORO.

556-582. Technical Information Center, ERDA-ORO.

582-1000. Regional and Urban Studies Distribution, Social Impact Assessment Group. 